\title{
Valorization of the Red Algae Gelidium sesquipedale by Extracting a Broad Spectrum of Minor Compounds Using Green Approaches
}

\author{
Natalia Castejón ${ }^{1,2, *,+} \mathbb{D}$, Maroussia Parailloux ${ }^{1}$, Aleksandra Izdebska ${ }^{1}$, Ryszard Lobinski ${ }^{1}$ \\ and Susana C. M. Fernandes $1,2,3, *$ \\ 1 Universite de Pau et des Pays de l'Adour, IPREM, E2S UPPA, CNRS, 64600 Anglet, France; \\ m.parailloux@univ-pau.fr (M.P.); aizdebska@univ-pau.fr (A.I.); ryszard.lobinski@univ-pau.fr (R.L.) \\ 2 MANTA-Marine Materials Research Group, Universite de Pau et des Pays de l'Adour, E2S UPPA, \\ 64600 Anglet, France \\ 3 Polymer Chemistry, Department of Chemistry—Angstrom Laboratory, Uppsala University, \\ Lagerhyddsvagen 1, 75120 Uppsala, Sweden \\ * Correspondence: natalia.castejon@univie.ac.at (N.C.); susana.fernandes@univ-pau.fr (S.C.M.F.) \\ + Present address: Department for Food Chemistry and Toxicology, University of Vienna, 1090 Vienna, Austria.
}

\section{check for}

updates

Citation: Castejón, N.; Parailloux, M.; Izdebska, A.; Lobinski, R.; Fernandes, S.C.M. Valorization of the Red Algae Gelidium sesquipedale by Extracting a Broad Spectrum of Minor Compounds Using Green Approaches. Mar. Drugs 2021, 19, 574 https://doi.org/10.3390/ md19100574

Academic Editor: William Lindsey White

Received: 19 September 2021

Accepted: 13 October 2021

Published: 14 October 2021

Publisher's Note: MDPI stays neutral with regard to jurisdictional claims in published maps and institutional affiliations.

Copyright: (c) 2021 by the authors. Licensee MDPI, Basel, Switzerland. This article is an open access article distributed under the terms and conditions of the Creative Commons Attribution (CC BY) license (https:// creativecommons.org/licenses/by/ $4.0 /)$.
Abstract: Until now, the red algae Gelidium sesquipedale has been primarily exploited for agar production, leaving an undervalued biomass. In this work, the use of eco-friendly approaches employing ultrasound-assisted extraction (UAE) and green solvents was investigated to valorize the algal minor compounds. The green methods used herein showed an attractive alternative to efficiently extract a broad spectrum of bioactive compounds in short extraction times (15 to $30 \mathrm{~min}$ vs. $8 \mathrm{~h}$ of the conventional method). Using the best UAE conditions, red seaweed extracts were characterized in terms of total phenolics (189.3 $\pm 11.7 \mathrm{mg} \mathrm{GAE} / 100 \mathrm{~g} \mathrm{dw}$ ), flavonoids (310.7 $\pm 9.7 \mathrm{mg}$ QE/100 g dw), mycosporine-like amino acids (MAAs) $(\Sigma$ MAAs $=1271 \mathrm{mg} / 100 \mathrm{~g} \mathrm{dw})$, and phycobiliproteins (72.4 $\pm 0.5 \mathrm{mg} / 100 \mathrm{~g} \mathrm{dw})$. Additionally, produced algal extracts exhibited interesting antioxidant and anti-enzymatic activities for potential applications in medical and/or cosmetic products. Thus, this study provides the basis to reach a superior valorization of algal biomass by using alternative methods to extract biologically active compounds following eco-friendly approaches. Moreover, the strategies developed not only open new possibilities for the commercial use of Gelidium sesquipedale, but also for the valorization of different algae species since the techniques established can be easily adapted.

Keywords: ultrasound-assisted extraction; eco-friendly methods; green extraction; macroalgae; bioactive compounds; mycosporine-like amino acids; phycobiliproteins

\section{Introduction}

Marine sources, especially seaweeds and microalgae are still an unexploited reservoir of bioactive compounds, which have significant potential to provide novel and natural ingredients for food and pharmaceutical industries [1,2].

Up to now, the red algae Gelidium sesquipedale has been mainly commercially exploited for agar production [3], leaving a large undervalued algal biomass. The industrial extraction process for agar generates extreme amounts of by-products that are basically used as fertilizer or frequently discarded since they are considered waste [4]. However, food processing by-products obtained from plants or algae are known as important sources of functional bioactive compounds [5,6]. Moreover, in the current context of global warming, the European Union (EU) is aiming to ensure the sustainability of the marine environments through its environmental and fisheries policies. The EU Blue Growth initiative represents a long-term strategy to support growth in the maritime sector as a whole by using the unexploited potential of oceans, seas, and coasts for economic growth [7]. A critical concern under this initiative is the valorization of algal biomass. EU objectives include not only 
the optimization of existing bioprocesses at the industry level, but also the quest for new products and/or environmental processes that improve the overall economic feasibility of algal biomass [8]. Thus, the search for new approaches that will successfully increase the value of algal biomass using minimum energy is nowadays a primary goal.

There are signs in the literature of the effective nutritional value and biological activities from Gelidium sesquipedale extracts, such as anti-enzymatic, antimicrobial, antioxidant, anti-inflammatory, or cytotoxic activities [9-11]. Moreover, the fatty acid composition, the total phenolic (TPC) and total flavonoid (TFC) contents, the identification of functional low-molecular-weight carbohydrates, the recovery of proteins and the detection of mycosporine-like amino acids (MAAs) have been reported in the literature [12-16], showing the potential of Gelidium sesquipedale biomass. Nevertheless, extraction methods commonly used for the isolation of these bioactive compounds are based on conventional techniques, which imply long extraction times, the use of high volumes of organic solvents, and high energy requirements, producing environmental and health problems [17].

Commercial interest in more sustainable and greener extraction approaches has increased during the past years, driven by growing consumer demands for more eco-friendly alternatives and natural ingredients that do not involve toxic chemicals. In this sense, ultrasound-assisted extraction (UAE) is a key technology in achieving the aims of sustainable chemistry and green extraction. Using $\mathrm{UAE}$, selective extractions can be done in minutes with high reproducibility, reducing the consumption of toxic solvents, simplifying manipulation, and consuming only a fraction of the energy normally needed for the conventional solid-liquid extraction methods, such as Soxhlet extraction, maceration or distillation [18].

On the other hand, one of the most critical points in the extraction of bioactives from seaweeds is the selection of the extraction technique, due to the presence of a dense and firm cell wall [19]. For that reason, the seaweed cell wall must be properly disrupted to efficiently recover intracellular bioactive compounds [20]. In this regard, UAE could be the key to develop new and environmentally friendly extraction methods for seaweed biomass, due to its proven effective action in cell membranes and cost-competitive results [21]. UAE implies the use of ultrasound waves generated by a water bath or an ultrasonic probe which produce cell disruption and facilitates the extraction by the cavitation phenomenon. In recent years, ultrasound technology has been widely applied for green and economically viable extractions of valuable compounds from marine sources [22].

Therefore, the main objective of this study was to valorize the minor compounds of the red algae Gelidium sesquipedale by using eco-friendly extraction approaches in combination with green solvents. To extract the broad spectrum of bioactives, extraction conditions using ultrasound treatment with ethanol, water, and their mixtures as solvents were optimized to achieve green alternatives. Red seaweed extracts were characterized in terms of polyphenol, flavonoid, MAAs, and phycobiliprotein contents. Moreover, antioxidant properties and enzymatic inhibitory activities were evaluated by using in vitro activity assays. The results presented in this work will provide the basis for the development of alternative strategies to extract biologically active compounds following the principles of Green Chemistry to reach a superior valorization of algal biomass.

\section{Results and Discussion}

\subsection{Total Phenolic and Flavonoid Contents of Red Seaweed Extracts}

Polyphenols are one of the largest and most widely distributed groups of seaweed phytochemicals, which have gained special attention due to their pharmacological activity and health-promoting benefits [23]. Even though it is known that red seaweeds are not the main source of phenolic and flavonoids compounds, these metabolites are targeted compounds for the valorization of the minor compounds from Gelidium sesquipedale.

Figure 1 shows the effects of UAE treatment time ( 15 and $30 \mathrm{~min}$ ), temperature (RT and $40{ }^{\circ} \mathrm{C}$ ), and solvent used (ethanol, water, and aqueous ethanolic solutions (50\% and $70 \%$ 
$v / v)$ ) on total phenolic (Figure 1a) and total flavonoid (Figure 1b) contents in comparison with the traditional extraction method.

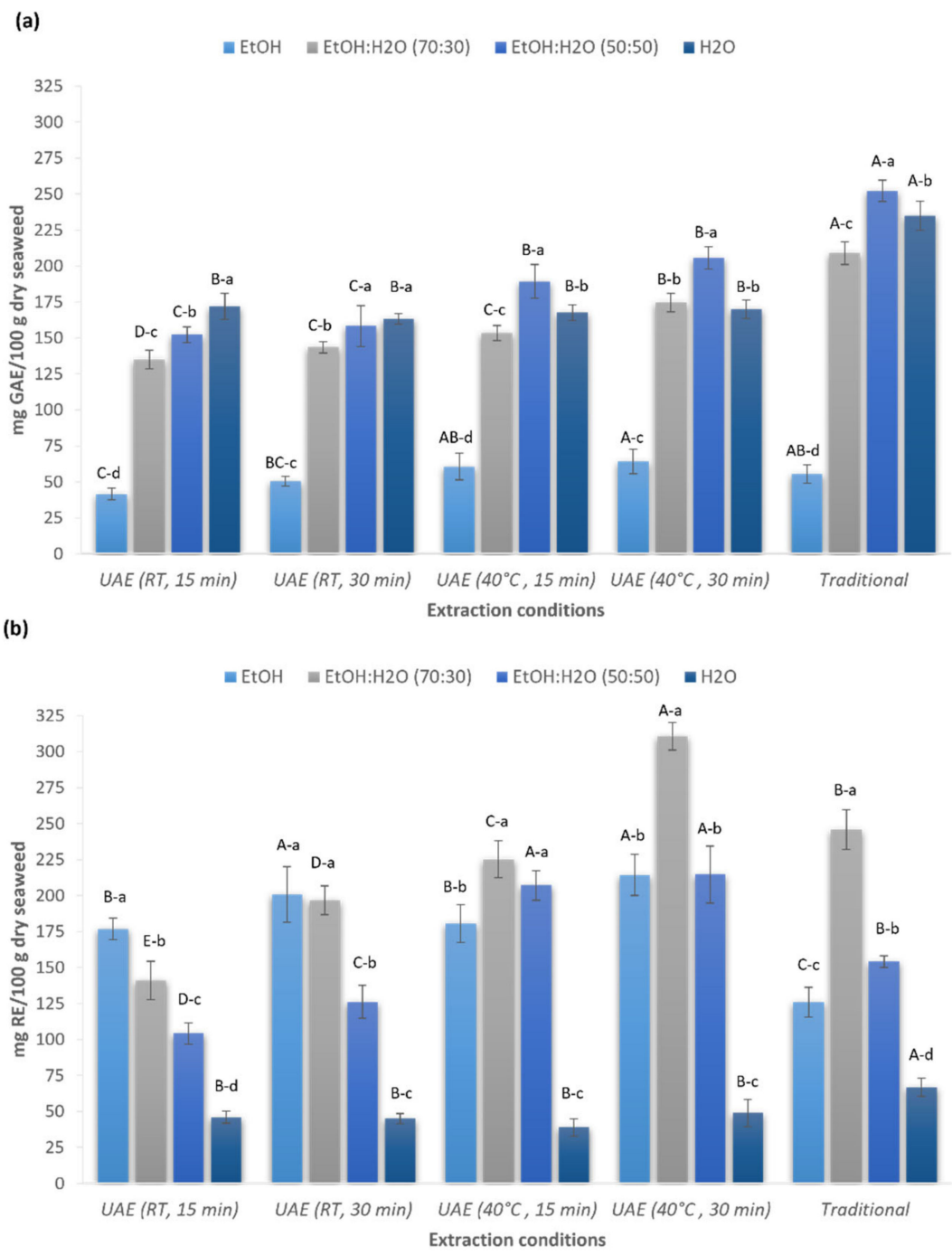

Figure 1. Effect of ultrasound-assisted extraction process parameters (time, temperature, and solvents) on total polyphenol (a) and total flavonoid (b) content of Gelidium sesquipedale seaweed. TPC (total phenolic content) and TFC (total flavonoid content) are expressed as mg gallic acid equivalents (GAE)/100 g dry algae, and mg quercetin equivalents (QE)/100 g dry algae, respectively. Data are shown as mean $\pm \mathrm{SD}(\mathrm{n}=9)$. Capital letters indicate statistically significant differences in extraction conditions and lowercase letters indicate statistically significant differences in solvents (one-way ANOVA with post-hoc Tukey, $p<0.05$ ).

Significant differences were found in the TPC between the different extraction conditions and solvents used, ranging from 41.5 to $252.2 \mathrm{mg} \mathrm{GAE} / 100 \mathrm{~g} \mathrm{dw}$. Among the solvents investigated, ethanol:water $(50: 50 \mathrm{v} / \mathrm{v})$ was the most effective solvent for the extraction of TPC except for the extracts produced with ultrasounds at room temperature, where water was also shown to be a good solvent to extract polyphenols (Figure 1a). The highest phenolic content was achieved with the conventional method using ethanol:water $(50: 50 v / v)(252.2 \pm 7.3 \mathrm{mg} \mathrm{GAE} / 100 \mathrm{~g} \mathrm{dw})(p<0.05$ in comparison with UAE treatments). Regarding the studied UAE conditions, no significant differences $(p>0.05)$ were found for the extracts obtained using ethanol:water $(50: 50 \mathrm{v} / \mathrm{v})$ at $40{ }^{\circ} \mathrm{C}$ during 15 and $30 \mathrm{~min}$ (189.3 $\pm 11.7 \mathrm{mg} \mathrm{GAE} / 100 \mathrm{~g} \mathrm{dw}$ and $205.6 \pm 7.7 \mathrm{mg}$ GAE$/ 100 \mathrm{~g} \mathrm{dw}$, respectively). Therefore, $\mathrm{UAE}$ at $40^{\circ} \mathrm{C}$ for $15 \mathrm{~min}$ is a less time-consuming alternative to extract TPC. Even though the UAE approaches proposed in this study did not achieve the maximum recovery 
of TPC obtained by the traditional method, the application of ultrasounds could be an attractive alternative due to the shorter extraction time (15 min vs. $8 \mathrm{~h}$ ), obtaining an extraction efficiency of $81 \%$ (extraction efficiency calculated considering the maximum TPC extracted with the traditional method).

A more interesting finding was observed during the extraction of flavonoids. UAE was found to be more effective in the extraction of flavonoid compounds (Figure 1b). Compared to the traditional method, ultrasound treatment significantly improved the extraction efficiency of flavonoids $(p<0.05)$. Among the solvents investigated, ethanol:water $(70: 30 v / v)$ showed the highest recovery of flavonoid compounds, with $40^{\circ} \mathrm{C}$ and $30 \mathrm{~min}$ being the best conditions to extract these bioactive compounds from the red algae ( $310.7 \pm 9.7 \mathrm{mg} \mathrm{QE} / 100 \mathrm{~g} \mathrm{dw})$ ( $p<0.05$ for all the conditions tested in this study). Using the optimized UAE conditions, the content of flavonoids increase 1.3 times in comparison with the traditional method, showing the potential of ultrasounds to extract flavonoid compounds from algal biomass in a short time. These results were in agreement with other authors that also reported the use of ethanol:water $(70: 30 \mathrm{v} / \mathrm{v})$ as the best solvent mixture to extract flavonoids from different vegetal sources [24-26] and seaweeds [27]. Similar results were obtained by Ummat et al. [28], who studied the TPC and TFC of 11 seaweed extracts from different species using the conventional solvent extraction and UAE. The authors also concluded that UAE was more effective than the traditional extraction in terms of total phenolic and flavonoid contents.

Other authors have already investigated the extraction of phenolic and flavonoid compounds from Gelidium sesquipedale, however using organic and toxic solvents and/or traditional extraction methods. For instance, Metidji et al. [29] reported a phenolic content ranging from 3.49 to $101.05 \mathrm{mg} \mathrm{GAE} / \mathrm{g}$ dried extract and a lower content of flavonoids (ranging from 0.85 to $5.63 \mathrm{mg} \mathrm{QE} / \mathrm{g}$ dried extract) using different mixtures of organic solvents like chloroform, methanol, diethyl ether or n-butanol. In another study, Grina et al. [10] described the phenolic and flavonoid contents of Gelidium sesquipedale extracts, but using higher temperatures than in the present study. Using the classical solvent extraction method with $70 \%$ ethanol at $60^{\circ} \mathrm{C}$ for $2 \mathrm{~h}$, the authors described a phenolic content of $11.1 \pm 0.03 \mu \mathrm{g}$ pyrocatechol equivalents (PE) $/ \mathrm{mg}$ extract and a flavonoid content of $5.84 \pm 0.02 \mu \mathrm{g} \mathrm{QE} / \mathrm{mg}$ extract. Matos et al. [13] also studied the phenolic content of Gelidium sesquispedale using ethanol ( $86 \pm 6 \mathrm{mg}$ GAE $/ 100 \mathrm{~g} \mathrm{dw})$ and water $(70 \pm 6 \mathrm{mg}$ $\mathrm{GAE} / 100 \mathrm{~g} \mathrm{dw}$ ) as solvents; however, the authors did not detail the extraction conditions or method used. Moreover, Xu et al. [30] described a phenolic content of $16.2 \pm 1.0 \mathrm{mg}$ GAE/g dry extract using ethanol but applying longer extraction times (24 and $48 \mathrm{~h}$ ) than in the present study. Therefore, the alternative strategies reported in this study showed clear advantages for the extraction of phenolic and flavonoid compounds from Gelidium sesquipedale using green approaches and eco-friendly solvents in shorter extraction times.

\subsection{Profiling of Mycosporines and Mycosporine-like Amino-Acids (MAAs) in Red Seaweed Extracts}

Mycosporines and MAAs are a large family of natural molecules, which have exceptional ultraviolet-absorbing capacities. They are perfect candidates to produce high-value products due to their high abundance in red algae and extraction facility, remaining easily transposable at an industrial scale [31-33]. Moreover, these metabolites have been the subject of numerous researches in cosmetic and biomedical fields because of their potent photoprotective and antioxidant bioactivities [34-36].

As a first attempt to evaluate the best strategy to extract mycosporines and MAAs from Gelidium sesquipedale, the UV-visible absorption spectra of red seaweed extracts were analyzed (Figure S1 from the Supplementary Materials). Results suggested that water was the most promising solvent to recover MAAs with high purity since the other solvents used also showed the presence of other minor compounds. Therefore, water extracts produced by UAE approaches and the traditional method were selected to analyze the MAAs profile and their quantification using advanced methods (Table 1). 


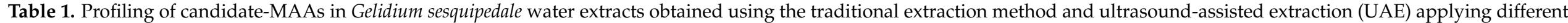
extraction times (15 and $30 \mathrm{~min}$ ) and temperatures (RT and $40^{\circ} \mathrm{C}$ ).

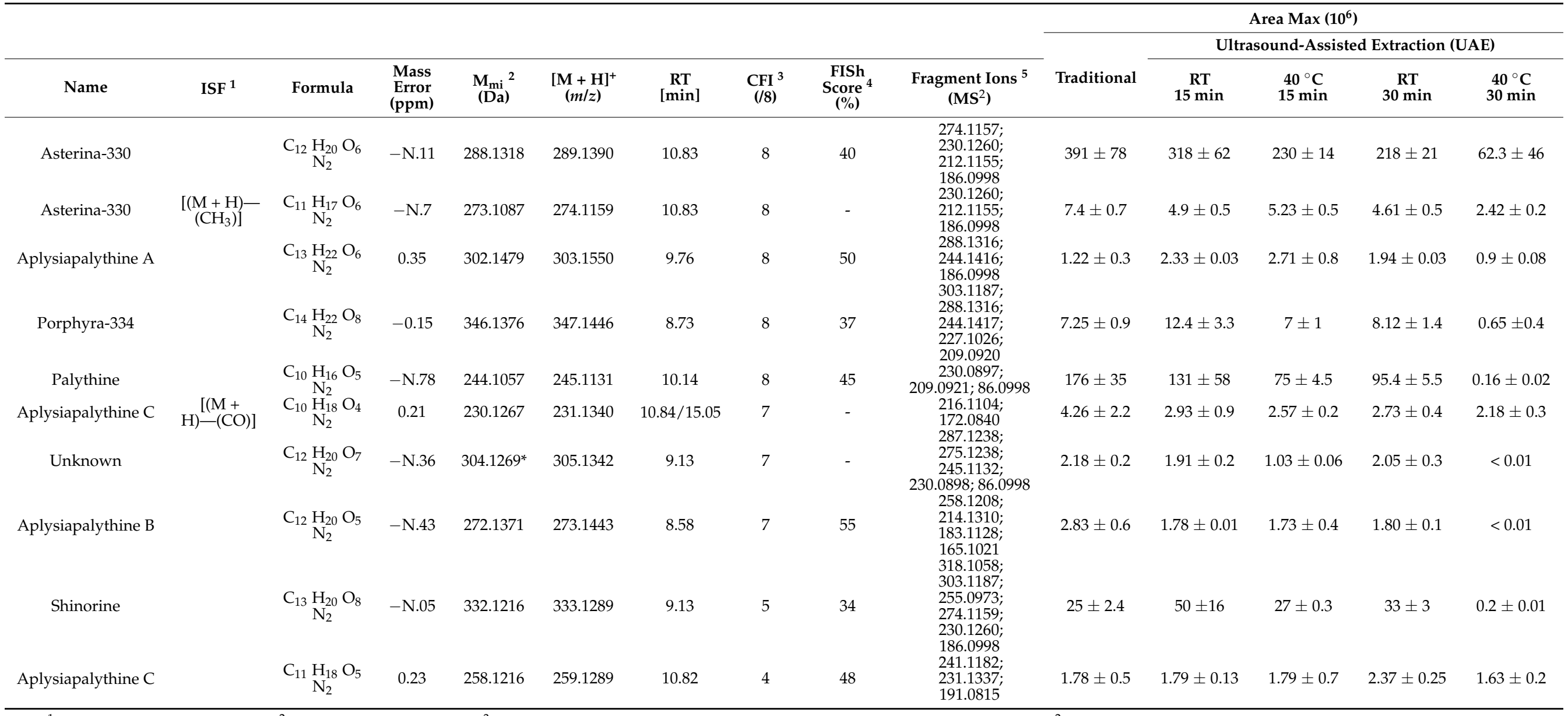

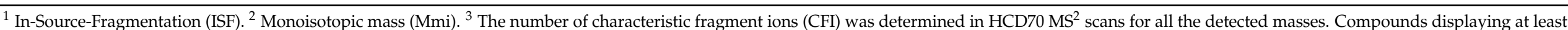

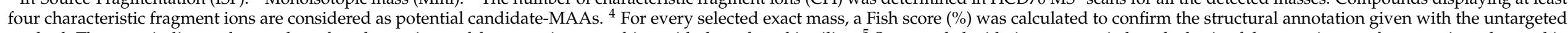

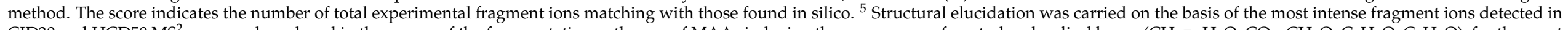

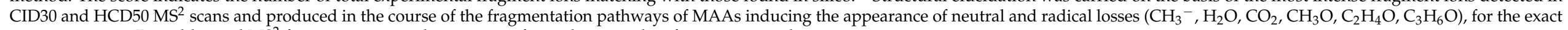
mass 304.1269. * Da, additional $\mathrm{MS}^{2}$ fragmentation analysis was performed to complete fragmentation data. 
The screening of MAAs was performed using an untargeted ddMS ${ }^{2} / \mathrm{MS}^{3}$ analysis allowing an annotation of candidate-compounds based on a set of fragment ions, and neutral and radical losses specific to their fragmentation pathways acquired in positive ionization mode [15]. Data-processing using an untargeted workflow on Compound Discoverer ${ }^{\mathrm{TM}}$ software allowed the inventory of tens of putative-MAAs with a signal intensity greater than $1 \times 10^{5}$ and more than four characteristic fragment ions in their HCD70 MS 2 spectra (Table 1, Figure S2 from the Supplementary Materials). The identified compounds belonged mainly to the palythine and glycine families, thus confirming their predominance in red macroalgae [37]. Interestingly, two $m / z$ values $(m / z 231.1340$ and $m / z$ 305.1342) were reported as unknown compounds (Figure S2 from the Supplementary Materials). The detection of seven characteristic fragment ions in their HCD70 MS ${ }^{2}$ spectrum confirmed their affiliation to the MAAs compound class. Notably, there is no significant difference between the different extraction procedures in the MAAs distribution, except for the extracts produced by UAE at $40^{\circ} \mathrm{C}$ for $30 \mathrm{~min}$, for which only eight compounds showed a signal above the defined intensity threshold.

In parallel, the extraction efficiency of the different UAE procedures was determined by the quantification of the most predominant MAAs: porphyra-334, shinorine, palythine and asterina-330 (Table 2). The quantitative study was based on a standard addition method with purified forms of palythine, shinorine and porphyra-334. The concentration of asterina-330 was determined using a semi-quantitative strategy based on the electrospray MS response factor similar (within 10\%) to the available standards for which it displays structural relationships [15].

Table 2. Quantification of asterina-330, porphyra-334, palythine and shinorine in Gelidium sesquipedale water extracts obtained using the traditional method and ultrasound-assisted extraction (UAE), applying different extraction times (15 and $30 \mathrm{~min}$ ) and temperatures (RT and $40^{\circ} \mathrm{C}$ ).

\begin{tabular}{cccccc}
\hline & \multicolumn{3}{c}{ MAAs Content (mg/100 g dw) } \\
\hline $\begin{array}{c}\text { Extraction } \\
\text { Method }\end{array}$ & Asterina-330 & Porphyra-334 & Palythine & Shinorine & $\Sigma$ MAAs \\
\hline Traditional method & $832.4 \pm 166.3^{\mathrm{a}}$ & $37.4 \pm 4.6^{\mathrm{b}}$ & $374.3 \pm 74.6^{\mathrm{a}}$ & $127.9 \pm 12.3^{\mathrm{b}}$ & $1372 \pm 253.8^{\mathrm{a}}$ \\
UAE RT 15 min & $676.2 \pm 131.7^{\mathrm{ab}}$ & $63.6 \pm 16.8^{\mathrm{a}}$ & $279.5 \pm 123.9^{\mathrm{ab}}$ & $252.5 \pm 82.1^{\mathrm{a}}$ & $1271 \pm 352.9^{\mathrm{ab}}$ \\
UAE RT $30 \mathrm{~min}$ & $468.4 \pm 44.8^{\mathrm{bc}}$ & $42.2 \pm 7.0^{\mathrm{ab}}$ & $205.2 \pm 11.8^{\mathrm{b}}$ & $171.0 \pm 15.5^{\mathrm{a}}$ & $886 \pm 74.2^{\mathrm{b}}$ \\
UAE $40^{\circ} \mathrm{C} 15 \mathrm{~min}$ & $494.4 \pm 30.7^{\mathrm{bc}}$ & $36.5 \pm 5.5^{\mathrm{b}}$ & $161.6^{\mathrm{b}} \pm 9.6^{\mathrm{c}}$ & $139.5 \pm 1.5^{\mathrm{b}}$ & $832 \pm 43.9^{\mathrm{b}}$ \\
UAE $40^{\circ} \mathrm{C} 30 \mathrm{~min}$ & $134.7 \pm 98.0^{\mathrm{d}}$ & $3.8 \pm 2.0^{\mathrm{c}}$ & $0.94 \pm 0.04^{\mathrm{d}}$ & $1.31 \pm 0.07^{\mathrm{c}}$ & $144^{\mathrm{c}} \pm 97.9^{\mathrm{c}}$ \\
\hline
\end{tabular}

Data are shown as mean $\pm \mathrm{SD}(\mathrm{n}=3)$; content of mycosporine-like amino acids (MAAs) is expressed as mg of MAAs/100 $\mathrm{g}$ dry algae; lowercase letters indicate statistically significant differences in columns (one-way ANOVA with post-hoc Tukey, $p<0.05$ ).

The results showed the MAAs yield of the different UAE procedures varied as a function of the temperature and the duration of the extractions. The algal extracts produced by UAE for $15 \mathrm{~min}$ at room temperature yielded the greatest MAAs concentrations. The efficiency of this alternative method was comparable to those obtained with the traditional procedure ( $\sum$ MAAs $1271 \pm 352.9 \mathrm{mg} / 100 \mathrm{~g} \mathrm{dw}$ and $1372 \pm 253.8 \mathrm{mg} / 100 \mathrm{~g} \mathrm{dw}$, respectively). Interestingly, extraction yields using UAE for 15 min was even higher $(p<0.05)$ than those achieved with UAE for $30 \mathrm{~min}$ ( $\sum$ MAAs $1372 \pm 253.8 \mathrm{mg} / 100 \mathrm{~g} \mathrm{dw}$ and $886 \pm 74.2 \mathrm{mg} / 100 \mathrm{~g} \mathrm{dw}$, respectively). Optimization of the extraction yields by applying temperature has been also investigated. Results showed that an increase of temperature resulted in a significant decrease of MAAs content $(p<0.05)$. Moreover, extraction yields obtained by UAE for $15 \mathrm{~min}$ at $40^{\circ} \mathrm{C}$ were ten to 100 -fold higher than UAE for $30 \mathrm{~min}$ at $40^{\circ} \mathrm{C}$, assuming MAA instability in a long-term temperature application.

In literature, the quantification of MAAs in Gelidium sesquipedale-based eco-friendly extraction methods have not yet been reported. A prior study dealing with quantification of MAAs in Ptercladiela capillacea and Gelidium amansii employed classical extractions based on methanol $25 \%(v / v)$ for $2 \mathrm{~h}$ at $45{ }^{\circ} \mathrm{C}$ and determined shinorine as the most predominant in Gelidium amansii [38]. Therefore, the application of ultrasounds for $15 \mathrm{~min}$ 
can be considered as a fast and valuable alternative to extract MAAs in comparison to the conventional method, which usually involves multistep processes. Interestingly, asterina330 showed the greatest amounts in all extraction conditions, which assumed its specificity to the algal species Gelidium sesquipedale [31].

\subsection{Antioxidant Activity of Red Seaweed Extracts}

The antioxidant capacity of red seaweed extracts produced by UAE and conventional extraction methods was measured using 1,1-diphenyl-2-picryl-hydrazyl (DPPH) and ferric reducing antioxidant power (FRAP) assays (Figure 2).

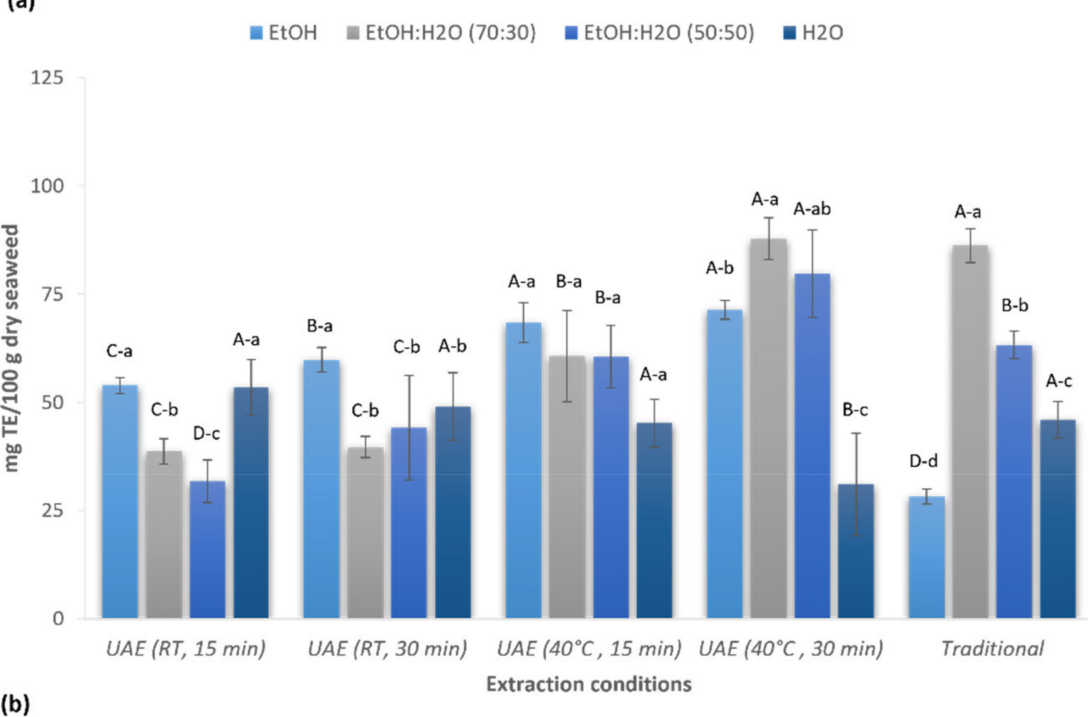

(b)

= EtOH = EtOH:H2O (70:30) — EtOH:H2O (50:50) — $\mathrm{H} 2 \mathrm{O}$

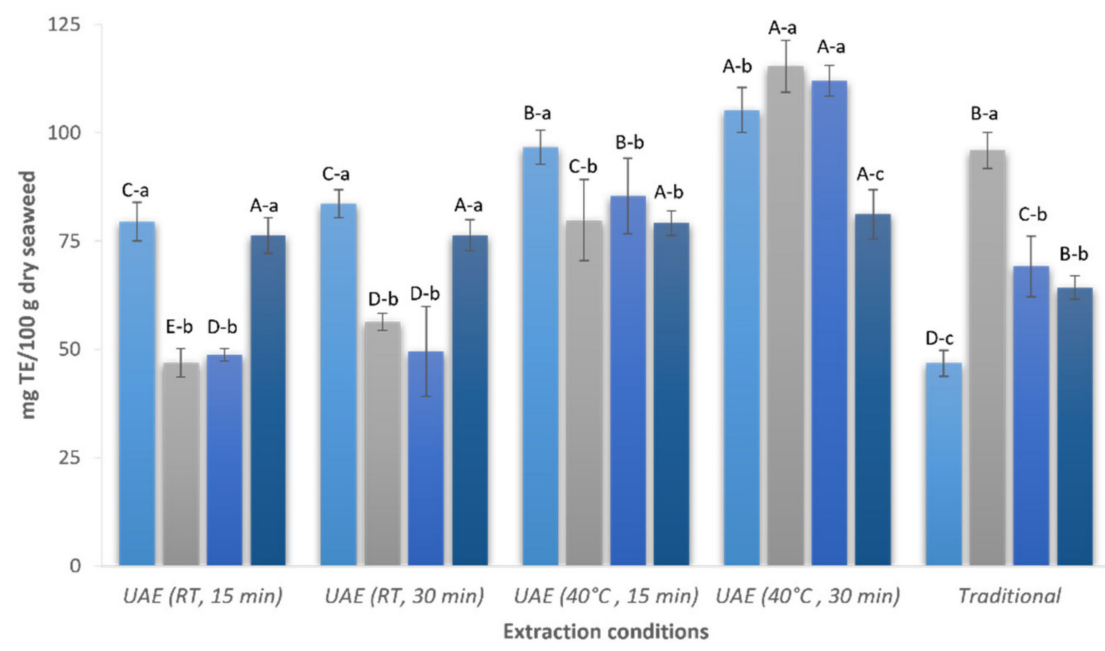

Figure 2. Antioxidant capacity measured as 1,1-diphenyl-2-picryl-hydrazyl (DPPH) activity (a) and ferric reducing antioxidant power (FRAP) (b) of Gelidium sesquipedale extracts using UAE and conventional solvent extraction techniques. DPPH and FRAP: expressed as mg trolox equivalent (TE)/g of $100 \mathrm{~g}$ dry algae. Data are shown as mean $\pm \mathrm{SD}(\mathrm{n}=9)$. Capital letters indicate statistically significant differences in extraction conditions, and lowercase letters indicate statistically significant differences in solvents (one-way ANOVA with post-hoc Tukey, $p<0.05$ ).

There was a statistically significant influence observed between extraction conditions and solvent type used $(p<0.05)$. The strongest DPPH free radical scavenging activity was shown by the extract produced by UAE at $40{ }^{\circ} \mathrm{C}$ during $30 \mathrm{~min}(87.7 \pm 4.8 \mathrm{mg} \mathrm{TE} / 100 \mathrm{~g} \mathrm{dw})$ 
and the traditional extraction method $(86.2 \pm 3.9 \mathrm{mg}$ TE/100 $\mathrm{g} \mathrm{dw})$ using in both cases ethanol:water $(70: 30 v / v)$ as the solvent $(p>0.05)$, while the highest FRAP value was shown by the extract obtained using UAE $(115.3 \pm 5.9 \mathrm{mg}$ TE/100 $\mathrm{g} \mathrm{dw})$ with the same extraction conditions previously described $(p<0.05$ in comparison with the traditional method). In contrast with the results achieved by the traditional method, the extract produced using ethanol:water $(50: 50 \mathrm{v} / \mathrm{v})$ by UAE at $40{ }^{\circ} \mathrm{C}$ during $30 \mathrm{~min}$ exhibited similar DPPH $(79.8 \pm 10.1 \mathrm{mg}$ TE/100 $\mathrm{g} \mathrm{dw})$ and FRAP $(112.0 \pm 3.6 \mathrm{mg}$ TE/100 $\mathrm{g} \mathrm{dw})$ values than ethanol:water $(70: 30 v / v)(p>0.05)$; consequently, the best antioxidant activity could be achieved using UAE with both ethanolic mixtures. Conversely, the weakest DPPH free radical scavenging activity $(28.3 \pm 1.7 \mathrm{mg}$ TE/100 $\mathrm{g} \mathrm{dw})$ and the lowest FRAP value $(46.8 \pm 3.0 \mathrm{mg}$ TE/100 $\mathrm{g} \mathrm{dw})$ was shown by the extract produced using the traditional method with pure ethanol.

Overall, the extracts produced using UAE showed similar or even higher (using the FRAP assay) antioxidant activity compared to the extracts obtained by the conventional method. It is known that the application of ultrasounds likely facilitated the release of bioactive compounds from seaweeds, and in consequence, extracts could exhibit a strong antioxidant capacity. Among the solvents tested, the aqueous ethanolic solutions (50\% and $70 \% v / v$ ) showed the most promising results. This was in agreement with the highest content of phenolic and flavonoid compounds shown in the present study, suggesting that it may be a positive correlation between the antioxidant activity and the TPC and TFC. A similar finding was reported by Chan et al., who described a positive role of the algal polyphenols extracted from the red seaweed Gracilaria changii as free radical scavengers and ferric ion reducing agents [39]. In a similar study, Zakaria et al. found synergistic effects of the phenolic compounds and the antioxidant capacity of the crude extracts of the red seaweed Acanthophora spicifera [40]. Moreover, Farasat et al. reported that the phenolic compounds, including flavonoids, are the main contributors to the antioxidant activity in different seaweed species [41].

Using ethanol and conventional solvent extraction, $\mathrm{Xu}$ et al. [30] reported the antioxidant capacity of different seaweeds, including Gelidium sp. collected from the coastline of eastern Guangdong in China. The authors showed a FRAP value of $16.1 \pm 1.1 \mathrm{mg}$ of gallic acid equivalent/g dry extract. In a similar study, Grina et al. [10] described the antioxidant activity of five seaweed species collected from the Moroccan Atlantic Ocean. The aqueous ethanolic extract ( $70 \%$ ethanol) of Gelidium sesquipedale produced by the traditional solvent extraction at $60{ }^{\circ} \mathrm{C}$ for $2 \mathrm{~h}$ were used to evaluate the antioxidant capacity with different methods: $\mathrm{DPPH}$ assay $\left(\mathrm{IC}_{50}=84.61 \pm 3.9 \mathrm{mg} / \mathrm{mL}\right), \beta$-carotene-linoleic acid assay $\left(\mathrm{IC}_{50}=75.36 \pm 3.6 \mathrm{mg} / \mathrm{mL}\right)$, ABTS assay $\left(\mathrm{IC}_{50}=44.46 \pm 2.4 \mathrm{mg} / \mathrm{mL}\right)$ and FRAP $\left(\mathrm{IC}_{50}=83.73 \pm 2.9 \mathrm{mg} / \mathrm{mL}\right)$. Conversely, Matos et al. [13] evaluated the antioxidant activity of water and ethanol extracts from Gelidium sesquipedale using the same antioxidant method proposed in the present study; however, the authors did not show any activity for the water extracts in terms of DPPH or FRAP and only a DPPH inhibition of $6.8 \%$ for the ethanol extract. The scarce studies about Gelidium sesquipedale in the literature, the utilization of several methods to evaluate the antioxidant activity, and the different units used to express the antioxidant capacity make the comparison of the results difficult.

\subsection{Extraction of Phycobiliproteins and Evaluation of Their Antioxidant Capacity}

Phycobiliproteins are the most important component of light-harvesting complexes in cyanobacteria and red algae. Phycobiliproteins from red algae, namely R-Phycoerythrin (R-PE) and R-Phycocyanin (R-PC), are water-soluble red and blue pigments, respectively. Moreover, phycobiliproteins have a great potential in food, cosmetics, and medical applications due to their antioxidant, radical-scavenging, and anti-inflammatories activities [42]. Extraction of phycobiliproteins from microalgae has been extensively reported in the literature, being the cyanobacteria Arthrospira Platensis the most popular commercial source [43]. Red algae are also a rich source of phycobiliproteins and could be targeted compounds for the valorization of algal biomass due to the high price of these extracts in the market [44]. 
For that reason, in this work, the extraction of phycobiliproteins using UAE and maceration to produce high added-value products was investigated (Table 3). To the extent of our knowledge, this is the first time that the extraction of phycobiliproteins using ultrasounds from the red algae Gelidium sesquipedale has been studied.

Table 3. Extraction of phycobiliproteins from Gelidium sesquipedale using different approaches and evaluation of the antioxidant capacity of produced extracts.

\begin{tabular}{|c|c|c|c|c|c|c|}
\hline Extraction Method & $\begin{array}{l}\text { R-PE Content } \\
\text { (mg/100 g) }\end{array}$ & $\begin{array}{c}\text { R-PC } \\
\text { Content } \\
(\mathrm{mg} / 100 \mathrm{~g})\end{array}$ & $\begin{array}{c}\text { Total } \\
\text { Content } \\
(\mathrm{mg} / 100 \mathrm{~g})\end{array}$ & $\begin{array}{c}\text { Extraction } \\
\text { Efficiency (\%) }\end{array}$ & $\begin{array}{c}\text { DPPH } \\
(\mathrm{mg} \mathrm{TE} / 100 \mathrm{~g})\end{array}$ & $\begin{array}{c}\text { FRAP } \\
(\mathrm{mg} \text { TE/100 g) }\end{array}$ \\
\hline $\begin{array}{c}\text { Traditional } \\
\text { Serial extraction }(5 \mathrm{~h}) \\
\text { Ultrasound (UAE) }\end{array}$ & $97.1 \pm 2.4^{a}$ & $50.2 \pm 1.6^{a}$ & $147.3 \pm 3.2^{\mathrm{a}}$ & 100 & $34.9 \pm 5.5^{\mathrm{d}}$ & $13.8 \pm 1.4^{\mathrm{d}}$ \\
\hline $\mathrm{UAE} 10 \mathrm{~min}$ & $37.5 \pm 1.0^{\mathrm{d}}$ & $17.4 \pm 0.7^{\mathrm{c}}$ & $54.7 \pm 1.6^{\mathrm{d}}$ & 37 & $41.4 \pm 3.3^{b c}$ & $21.7 \pm 0.2^{b}$ \\
\hline $\begin{array}{c}\text { UAE } 15 \text { min } \\
\text { Ultrasound + maceration } \\
(\text { Mac) }\end{array}$ & $37.6 \pm 1.3^{d}$ & $16.5 \pm 0.5^{\mathrm{c}}$ & $54.1 \pm 2.1^{\mathrm{d}}$ & 37 & $38.5 \pm 2.5^{\mathrm{cd}}$ & $17.3 \pm 1.6^{c}$ \\
\hline $\begin{array}{l}\text { UAE } 15 \mathrm{~min}+\text { Mac } 45 \mathrm{~min} \\
\text { UAE } 15 \mathrm{~min}+\text { Mac } 1 \mathrm{~h}\end{array}$ & $\begin{array}{l}48.3 \pm 1.5^{c} \\
52.4 \pm 1.3^{b}\end{array}$ & $\begin{array}{l}24.0 \pm 1.4^{b} \\
25.7 \pm 0.5^{b}\end{array}$ & $\begin{array}{l}72.4 \pm 0.5^{\mathrm{c}} \\
77.9 \pm 1.6^{\mathrm{b}}\end{array}$ & $\begin{array}{l}49 \\
53\end{array}$ & $\begin{array}{r}48.9 \pm 2.5^{\mathrm{a}} \\
45.6 \pm 2.8^{\mathrm{ab}}\end{array}$ & $\begin{array}{c}23.5 \pm 1.1^{\mathrm{a}} \\
22.6 \pm 0.8^{\mathrm{ab}}\end{array}$ \\
\hline
\end{tabular}

Data are shown as mean $\pm \mathrm{SD}(\mathrm{n}=3)$; phycobiliproteins (R-phycoerythrin, R-PE and R-phycocyanin, R-PC) contents are expressed as mg of phycobiliproteins $/ 100 \mathrm{~g}$ dry algae; DPPH and FRAP values are expressed as $\mathrm{mg}$ trolox equivalent $(\mathrm{TE}) / 100 \mathrm{~g}$ dry algae $(\mathrm{n}=9)$. Lowercase letters indicate statistically significant differences in columns (one-way ANOVA with post-hoc Tukey, $p<0.05$ ).

To estimate the maximum amount of phycobiliproteins that could be extracted from Gelidium sesquipedale biomass, a serial extraction using five consecutive cycles of $1 \mathrm{~h}(5 \mathrm{~h}$ of total extraction time) was carried out, achieving a total phycobiliprotein content of $147.3 \pm 3.1 \mathrm{mg} / 100 \mathrm{~g} \mathrm{dw}$. To develop alternative approaches to extract these valuable compounds, the application of ultrasound-assisted extraction was studied. For instance, two different extraction times were evaluated (10 and $15 \mathrm{~min})$. However, longer extraction times were not evaluated due to the thermo-sensitive nature of phycobiliproteins. The total phycobiliprotein content of ultrasound extracts was $54.7 \pm 1.6 \mathrm{mg} / 100 \mathrm{~g} \mathrm{dw}$ and $54.1 \pm 2.1 \mathrm{mg} / 100 \mathrm{~g} \mathrm{dw}$ for 10 and $15 \mathrm{~min}$, respectively, with a extraction efficiency of $37 \%$, showing that the application of ultrasound was not able to extract the total amount of phycobiliproteins present in the algal biomass. In consequence, the combination of ultrasound and maceration was also investigated. This idea was taken for a previous published study of Mittal et al. [45], in which the authors examined the extraction of phycobiliproteins from Gelidium pusillum using maceration followed by the application of ultrasound treatment. However, it is known that phycobiliproteins are intracellular compounds; thus, cell disruption is necessary to achieve maximal efficacy during the extraction process [46]. For that reason, in this work, the use of ultrasounds as a pretreatment followed by a maceration step to promote the release of phycobiliproteins into the medium was investigated. Specifically, a pre-treatment step using $15 \mathrm{~min}$ of ultrasound and two different maceration times ( $45 \mathrm{~min}$ and $1 \mathrm{~h}$ ) was investigated. As can be seen in Table 3, the combination of both methods significantly improves the extraction of phycobiliproteins in comparison with the use of ultrasound alone $(p<0.05)$. However, increasing the extraction time of the maceration step from 45 to $60 \mathrm{~min}$ did not produce the expected impact, and the phycobiliproteins content improved only slightly $(p<0.05)$. These results suggest that the application of different cycles is a key condition to extract the total amount of phycobiliproteins present in red algae, probably related with the saturation of the solvent. Nevertheless, compared with previous data published, the results shown in this study were in agreement with the content of phycobiliproteins reported by other authors using different Gelidium species. For instance, Mittal et al. [45] reported a phycobiliprotein content of 20 to $200 \mathrm{mg} / 100 \mathrm{~g}$ dry biomass for Gelidium pusillum depending on extraction conditions. In another study, Sukwong et al. [47] reported a R-PE and R-PC content of $10.9 \mathrm{mg} / 100 \mathrm{~g}$ for Gelidium amansii. 
Interesting results were found during the evaluation of the antioxidant capacity of produced extracts; the highest DPPH and FRAP values were exhibited by the extracts produced with the combination of ultrasound and maceration for $45 \mathrm{~min}$ (US $15 \mathrm{~min}+$ Mac $45 \mathrm{~min})(p<0.05)$. These results suggest that even the traditional extraction (serial extraction) was able to extract a higher content of total phycobiliproteins; the conventional method could induce the degradation of these compounds and consequently decrease the antioxidant activity of produced extracts ( $p<0.05$ for all the extracts tested). Therefore, the combination of ultrasound and maceration for $45 \mathrm{~min}$ seems to be the most promising strategy to extract the phycobiliproteins from Gelidium sesquipedale without losing their antioxidant capacity. Additionally, to further investigate the biological activity of phycobiliproteins, the extracts produced by the best conditions and the serial extraction to compare were evaluated in the following section.

\subsection{Anti-Enzymatic Activities of Red Seaweed and Phycobiliproteins Extracts}

In an attempt to find novel biological activities of Gelidium sesquipedale extracts, the inhibitory effects of produced extracts on acetylcholinesterase (AChE), tyrosinase, and elastase were evaluated. To the best of our knowledge, this is the first time that the enzymatic inhibitory activity of Gelidium sesquipedale extracts produced by ultrasound have been investigated. Moreover, data on this topic is scarce, and only a few studies have investigated the anti-enzymatic activities of Gelidium sesquipedale extracts.

In a first step, all red seaweed extracts produced were evaluated for their ability to inhibit the activity of different enzymes using a first screening approach (data not shown). However, the use of ethanol or its mixtures produced a negative effect on the activity of the enzymes investigated. For that reason, only the extracts produced by aqueous extraction (red seaweed extracts using water and phycobiliproteins extracts) were selected to evaluate their efficacy by measuring the half-maximal inhibitory concentration $\left(\mathrm{IC}_{50}\right)$ (Table 4).

Table 4. Acetylcholinesterase (AChE), tyrosinase and elastase inhibitory activities of aqueous red seaweed and phycobiliproteins extracts using UAE and conventional solvent extraction techniques.

\begin{tabular}{|c|c|c|c|}
\hline Samples & $\begin{array}{l}\text { AChE Assay } \\
\mathrm{IC}_{50}(\mathrm{mg} / \mathrm{mL})\end{array}$ & $\begin{array}{l}\text { Tyrosinase Assay } \\
\text { IC }_{50}(\mathrm{mg} / \mathrm{mL})\end{array}$ & $\begin{array}{l}\text { Elastase Assay } \\
\mathrm{IC}_{50}(\mathrm{mg} / \mathrm{mL})\end{array}$ \\
\hline \multicolumn{4}{|l|}{ Red seaweed extracts (water) } \\
\hline Traditional method & $36.3 \pm 3.1^{\mathrm{a}}$ & NI & NI \\
\hline UAE RT $15 \mathrm{~min}$ & $56.6 \pm 1.5^{b}$ & NI & NI \\
\hline UAE RT $30 \mathrm{~min}$ & $59.0 \pm 3.1^{b}$ & NI & $\mathrm{NI}$ \\
\hline $\mathrm{UAE} 40^{\circ} \mathrm{C} 15 \mathrm{~min}$ & $68.2 \pm 0.6^{c}$ & NI & NI \\
\hline $\mathrm{UAE} 40^{\circ} \mathrm{C} 30 \mathrm{~min}$ & $76.1 \pm 6.2^{\mathrm{c}}$ & NI & NI \\
\hline \multicolumn{4}{|l|}{ Phycobiliproteins extracts } \\
\hline Serial extraction $(5 \mathrm{~h})$ & $>100^{\mathrm{e}}$ & $>100^{b}$ & $>100^{b}$ \\
\hline $\begin{array}{c}\text { US } 15 \mathrm{~min}+\text { Mac } 45 \mathrm{~min} \\
\text { Positive standards }\end{array}$ & $94.3 \pm 0.2^{d}$ & $86.5 \pm 0.5^{a}$ & $87.4 \pm 0.4^{a}$ \\
\hline Neostigmine bromide & $0.06 \pm 0.01$ & NT & NT \\
\hline Kojic acid & NT & $0.05 \pm 0.01$ & NT \\
\hline Quercetin & NT & NT & $0.22 \pm 0.01$ \\
\hline
\end{tabular}

Data are shown as mean $\pm \mathrm{SD} ; \mathrm{IC}_{50}$ values represent the mean standard error of three parallel measurements; lowercase letters indicate statistically significant differences in columns (one-way ANOVA with post-hoc Tukey, $p<0.05) ; \mathrm{US}=$ ultrasound; $\mathrm{Mac}=$ maceration; $\mathrm{NT}=$ not tested; $\mathrm{NI}=$ no inhibition .

Acetylcholinesterase (AChE) is an enzyme that catalyzes the breakdown of acetylcholine to acetate and choline. It is also the potential target of most of the drugs used for the treatment of Alzheimer's disease [48]. In this study, the AChE inhibitory activity of aqueous red seaweed extracts and phycobiliproteins fractions was evaluated. Moreover, neostigmine bromide was used as a positive control as it is used to treat Alzheimer's patients [49]. As can be seen in Table 4, all seaweed extracts showed AChE inhibitory activity. Surprisingly, the aqueous extract produced by the traditional method was the most active among the other extracts investigated $(p<0.05)$. The anti-enzymatic activity 
decreased as the extraction temperature increased, exhibiting a negative correlation between the temperature and the activity of the extract. These results were in agreement with a previous study in which Grina et al. [10] reported a high $\mathrm{IC}_{50}$ value for a Gelidium sesquipedale extract $(>200 \mathrm{mg} / \mathrm{mL})$ produced using high temperature $\left(60^{\circ} \mathrm{C}\right.$ for $\left.2 \mathrm{~h}\right)$.

Additionally, the potential of produced extracts for possible cosmetics products was investigated. Specifically, the inhibitory activity of red algal extracts towards two enzymes was evaluated: tyrosinase and elastase. Tyrosinase plays an important role in the biosynthesis of melanin. For that reason, the downregulation of tyrosinase is one of the most prominent approaches for the development of whitening and lightening products with applications in the cosmetic industry [50]. Conversely, elastase is a protease that reduces elastin in the skin by dividing specific peptide bonds. Inhibitors of elastase can be used as cosmetic ingredients to prevent loss of skin elasticity and thus skin aging [51]. In this work, the phycobiliproteins fractions were the most active extracts towards tyrosinase and elastase, while the extracts produced using water did not show anti-enzymatic activities towards these enzymes. Furthermore, a positive effect of the phycobiliprotein extracts produced with UAE was demonstrated, suggesting that ultrasound treatment may extract a broader spectrum of bioactives that could contribute to these activities. Grina et al. [10] reported a $\mathrm{IC}_{50}$ value of tyrosinase for Gelidium sesquipedale extracts as higher than $200 \mathrm{mg} / \mathrm{mL}$. In another study, Oumaskour et al. reported an elastase inhibition greater than $95 \%$ with a dichloromethane-methanol $(50: 50 \mathrm{v} / \mathrm{v})$ extract from Gelidium sesquipedale; however, the authors did not provide information about the $\mathrm{IC}_{50}$ value [52].

From the results gathered, it is possible to conclude that the water and phycobiliprotein extracts produced by the conditions used in this work exhibited a wide range of inhibitory activities, being promising extracts with potential anti-enzymatic activities for medical and cosmetic applications. Although aqueous extracts from Gelidium sesquipedale showed promising results and may open new opportunities for the exploitation of natural enzymatic inhibitors from marine resources, further studies are needed to clarify the identity of the metabolites responsible for these biological effects.

\section{Materials and Methods}

\subsection{Materials}

\subsubsection{Algal Biomass}

Biomass of the red macroalgae Gelidium sesquipedale was provided by the Comite Interdépartemental des Pêches Maritimes et des Élevages Marins des Pyrénées Atlantiques et des Landes (CIDPMEM 64-40, Ciboure, France), which directly collected the algal biomass from the French Basque Coast at the end of September 2020. After the reception of the biomass, seaweeds were rinsed with tap water (to eliminate impurities), dried at room temperature for 2 weeks in a drying room, and milled using a laboratory ball mill (Planetary ball mill PM 100, Retsch GmbH, Germany). Samples were stored at $4{ }^{\circ} \mathrm{C}$ until their use.

\subsubsection{Chemicals}

Tyrosinase from mushroom, L-3,4-dihydroxyphenylalanine (L-DOPA), elastase from porcine pancreas, N Succinyl-Ala-Ala-Ala-p-nitroanilide (AAAPVN), Acetylcholinesterase (AChE) from Electrophorus electricus, acetylthiocholine iodide, DTNB (5,5'-dithiobis (2nitrobenzoic acid), 2,2-diphenyl-1-picrylhydrazyl (DPPH), 2,4,6-Tripyridyl-s-Triazine (TPTZ), Tris(hydroxymethyl)aminomethane, hydrochloric acid (36\%), Trolox, Folin Ciocaltue's reagent, gallic acid $(95 \%)$, rutin $(95 \%)$, quercetin $(97 \%)$ and neostigmine bromide were purchased from Sigma Chemical Co. (St. Louis, MO, USA). Kojic acid (Alfa Aesar ${ }^{\mathrm{TM}}$, 99\%), sodium phosphate monobasic monohydrate (ACROS Organics ${ }^{\mathrm{TM}}, 98+\%$ ) and sodium hydrogen phosphate (Alfa Aesar ${ }^{\mathrm{TM}}$, 98+\%) were provided by Fisher Scientific (Hampton, VA, USA). Ethanol absolute was purchased from Sodipro (Echirolles, France). All other chemicals and reagents used were analytical grade. The water used for the extraction and preparation of water-based solutions was Milli-Q grade (Millipore, Burlington, MA, USA). 


\subsection{Extraction Methods}

\subsubsection{Production of Red Seaweed Extracts}

To extract the broad spectrum of minor compounds from Gelidium sesquipedale, two methods were investigated: UAE and the traditional method to compare the extraction efficiency. UAE was optimized by studying different extraction conditions such as temperature, time, and solvent type (Table 5). Moreover, Table 5 shows the targeted bioactive or bioactivity evaluation of each algal extract.

Table 5. Experimental design for the extraction of different bioactive compounds and bioactivity evaluation of Gelidium sesquipedale using ultrasound-assisted extraction (UAE) and traditional extraction methods.

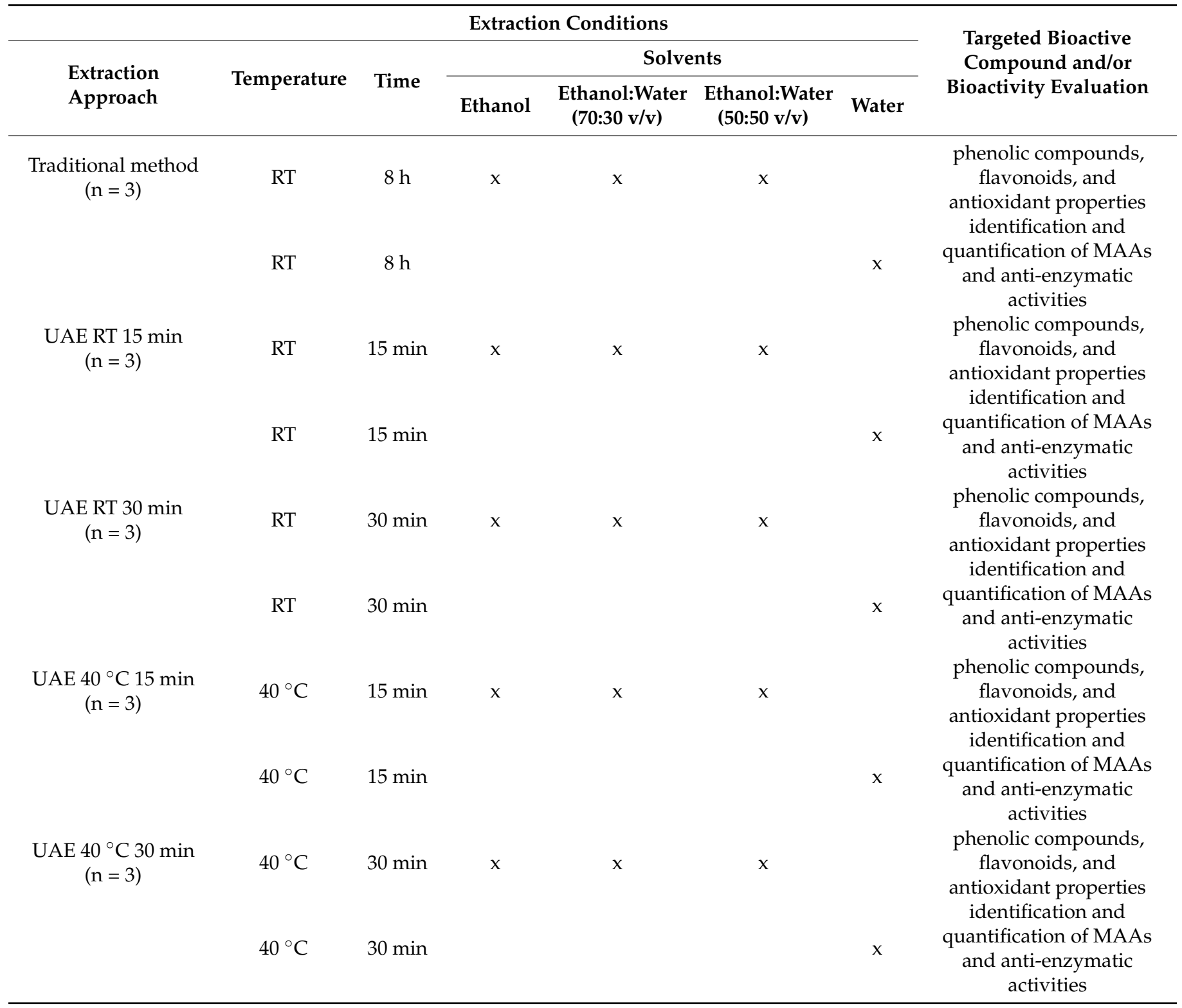

The extraction was carried out in triplicate for each group and every extract replicate was analyzed in triplicate.

\section{Ultrasound-Assisted Extraction}

UAE was carried out with an ultrasound bath (ULTR-3L2-001, Labbox Labware, S.L., Barcelona, Spain) with automatic control of time and temperature, an ultrasound frequency of $42 \mathrm{kHz}$ and ultrasonic power of $100 \mathrm{~W}$. Dried and milled red seaweed samples were dispersed in ethanol, or distilled water or aqueous ethanolic solutions $(50 \%$ and $70 \% v / v)$ at a ratio of 1:20 $(w / v)$. Different experiments were carried out using different parameters like 
temperature (room temperature (RT) and $40{ }^{\circ} \mathrm{C}$ ), and time (15 and $30 \mathrm{~min}$ ) (Table 5) [17]. After the treatment, samples were centrifuged at $4000 \times g$ for $5 \mathrm{~min}$. The supernatants collected were stored in dark vessels at $4{ }^{\circ} \mathrm{C}$ until their analysis. All extraction procedures were performed in triplicate.

\section{Conventional Solvent Extraction}

Traditional method was carried out to compare the efficacy of conventional solvent extraction with the UAE conditions determined in this study. Seaweed samples were extracted following the method described by Ummat et al. [28], with minor modifications. Briefly, dried and milled red seaweed samples were dispersed in ethanol, or distilled water or aqueous ethanolic solutions $(50 \%$ and $70 \% v / v)$ at a ratio of 1:20 $(w / v)$, and the biomolecules of interest were extracted in an orbital shaker (RT, $200 \mathrm{rpm}$ and for $4 \mathrm{~h}$ ). After the treatment, samples were centrifuged at $4000 \times g$ for $5 \mathrm{~min}$. The macroalgal pellet was re-extracted following the same procedure, and both supernatants were pooled together. Ethanol was evaporated in a rotary evaporator (Buchi R-100, BÜCHI Labortechnik AG, Switzerland) and the remaining aqueous fractions were freeze-dried. Extracts were redissolved in the same volume used for the ultrasound extracts. Samples were stored in dark vessels at $4{ }^{\circ} \mathrm{C}$ until their analysis. All extraction procedures were performed in triplicate.

\subsubsection{Production of Phycobiliproteins Extracts}

The extraction of phycobiliproteins from Gelidium sesquipedale was done following different methods using phosphate buffer $(0.1 \mathrm{M}, \mathrm{pH} 6.8)$ as a solvent: serial extraction (traditional), UAE, and a combination of UAE and maceration. Additionally, different parameters affecting the extraction of phycobiliproteins, such as ultrasonication and maceration times, were investigated (Table 6).

Table 6. Experimental design for the extraction of phycobiliproteins and bioactivity evaluation from Gelidium sesquipedale using ultrasound-assisted extraction (UAE) and traditional extraction methods.

\begin{tabular}{|c|c|c|c|c|c|}
\hline \multirow{3}{*}{ Extraction Approach } & \multicolumn{4}{|c|}{ Extraction Conditions } & \multirow{3}{*}{$\begin{array}{l}\text { Targeted Bioactive } \\
\text { Compound and/or } \\
\text { Bioactivity Evaluation }\end{array}$} \\
\hline & \multicolumn{2}{|c|}{ Maceration } & \multicolumn{2}{|c|}{ Ultrasound } & \\
\hline & Temperature & Time & Temperature & Time & \\
\hline \multicolumn{6}{|l|}{ Traditional } \\
\hline Serial extraction $(n=3)$ & - & - & $-4^{\circ} \mathrm{C}$ & $5 \mathrm{~h}$ & $\begin{array}{l}\text { phycobiliproteins, antioxidant } \\
\text { properties and anti-enzymatic } \\
\text { activities }\end{array}$ \\
\hline \multicolumn{6}{|l|}{ Ultrasound (UAE) } \\
\hline UAE $10 \min (n=3)$ & RT & $10 \mathrm{~min}$ & - & - & $\begin{array}{c}\text { phycobiliproteins and antioxidant } \\
\text { properties }\end{array}$ \\
\hline UAE $15 \min (n=3)$ & RT & $15 \mathrm{~min}$ & - & - & $\begin{array}{l}\text { phycobiliproteins and antioxidant } \\
\text { properties }\end{array}$ \\
\hline \multicolumn{6}{|l|}{ Ultrasound + maceration $(U A E+M a c)$} \\
\hline $\mathrm{UAE} 15 \min +\operatorname{Mac} 45 \min (\mathrm{n}=3)$ & RT & $15 \mathrm{~min}$ & $-4^{\circ} \mathrm{C}$ & $45 \mathrm{~min}$ & $\begin{array}{l}\text { phycobiliproteins, antioxidant } \\
\text { properties and anti-enzymatic } \\
\text { activities }\end{array}$ \\
\hline UAE $15 \min +\operatorname{Mac} 1 \mathrm{~h}(\mathrm{n}=3)$ & RT & $15 \mathrm{~min}$ & $-4^{\circ} \mathrm{C}$ & $1 \mathrm{~h}$ & $\begin{array}{c}\text { phycobiliproteins and antioxidant } \\
\text { properties }\end{array}$ \\
\hline
\end{tabular}

The extraction was carried out in triplicate for each group and every extract replicate was analyzed in triplicate.

\section{Serial Extraction}

Serial extraction (traditional extraction method) was carried out to estimate the maximum extractable content of phycobiliproteins (R-phycoerythrin, R-PE and R-phycocyanin, R-PC) present in algal biomass. The traditional extraction was performed following a previously described protocol for Gelidium pusillum (Rhodophyta) [45] with minor modifications. 
Briefly, $2.5 \mathrm{~g}$ of Gelidium sesquipedale powder was macerated in $25 \mathrm{~mL}$ of phosphate buffer $\left(0.1 \mathrm{M}, \mathrm{pH}\right.$ 6.8) for $1 \mathrm{~h}$ at $4{ }^{\circ} \mathrm{C}$ under constant stirring. After the extraction time, samples were centrifuged at $4000 \times g$ for $12 \mathrm{~min}$ at $4{ }^{\circ} \mathrm{C}$. The supernatant was collected for UV analysis and the pellet was submitted for another cycle of extraction with fresh solvent. This procedure was repeated until no detectable phycobiliproteins were extracted in the buffer ( 5 cycles) and the supernatants of each cycle were pooled together for spectrophotometric analysis. This process was used as a reference to estimate the maximum amount of phycobiliproteins that could be extracted. The serial extraction was done in triplicate.

Ultrasound-Assisted Extraction and Combination with Maceration

The UAE method was carried out as follows: $2.5 \mathrm{~g}$ of Gelidium sesquipedale powder were dispersed in $25 \mathrm{~mL}$ of phosphate buffer $(0.1 \mathrm{M}, \mathrm{pH}$ 6.8) and extraction was done in an ultrasonic bath at room temperature using different times: 10 and $15 \mathrm{~min}$. For the experiments using the combination of UAE and maceration, samples were treated as described before for the UAE method, followed by a maceration step. After ultrasonic treatment, samples were macerated in phosphate buffer $(0.1 \mathrm{M}, \mathrm{pH}$ 6.8) for different times (45 min and $1 \mathrm{~h}$ ) at $4{ }^{\circ} \mathrm{C}$ under constant stirring. After the treatments, samples were centrifugated at $4000 \mathrm{~g}$ for $12 \mathrm{~min}$ at $4{ }^{\circ} \mathrm{C}$ and the supernatants were collected for UV analysis. All extraction procedures were performed in triplicate.

\subsection{Determination of Total Phenolic Content (TPC)}

The TPC of seaweed extracts was determined according to the Folin-Ciocalteu method previously described [53,54], with slight modifications and using gallic acid (GA) as standard [55]. Briefly, in a 96-well plate (Thermo Scientific ${ }^{\mathrm{TM}}$ Multiskan Sky, Waltham, MA, USA), $20 \mu \mathrm{L}$ of or serial standard solution was mixed with $100 \mu \mathrm{L}$ of Folin-Ciocalteu reagent ( $10 \%$ in distilled water). After $5 \mathrm{~min}, 80 \mu \mathrm{L}$ of $7.5 \%(v / w)$ sodium carbonate solution was added. The reaction mixture was incubated at room temperature and darkness for $30 \mathrm{~min}$. The absorbance was measured at $750 \mathrm{~nm}$. The calibration curve was prepared by using gallic acid ethanolic solutions and phenolic content was expressed as mg gallic acid equivalents per $100 \mathrm{~g}$ of dry algae (mg GAE/100 g).

\subsection{Determination Total Flavonoid Content (TFC)}

The TFC of seaweed extracts was determined by following the colorimetric method previously described using rutin as standard [56]. Briefly, in a 96-well plate (Thermo Scientific ${ }^{\mathrm{TM}}$ Multiskan Sky, USA), $20 \mu \mathrm{L}$ of each extract were mixed with $20 \mu \mathrm{L}$ of $10 \%$ aluminum chloride, $20 \mu \mathrm{L}$ of $1 \mathrm{M}$ potassium acetate and $180 \mu \mathrm{L}$ of distilled water. The reaction mixture was incubated at room temperature and darkness for $30 \mathrm{~min}$. The absorbance was measured at $415 \mathrm{~nm}$. The calibration curve was prepared by using rutin methanolic solutions and flavonoid content was expressed as $\mathrm{mg}$ rutin equivalents per $100 \mathrm{~g}$ of dry algae (mg RE/100 g).

\subsection{Identification and Quantification of Mycosporines and MAAs}

\subsubsection{Chromatographic Conditions}

Experiments were performed on a HILIC Osaka Soda Capcell Core PC column $(2.1 \times 150 \mathrm{~mm}, 2.7 \mu \mathrm{m}, 90 \AA$ A) from BGB Analytics (Saint-Jean de Gonville, France). The mobile phases were: $5 \mathrm{mM}$ ammonium acetate in water at $\mathrm{pH} 5.3$ (A) and acetonitrile (B). The flow rate was fixed at $0.35 \mathrm{~mL} / \mathrm{min}$. The HPLC separation was carried out with the following gradient elution profile: $0-2 \mathrm{~min}, 10 \% \mathrm{~B} ; 2-6 \mathrm{~min}, 20 \% \mathrm{~B} ; 6-11 \mathrm{~min}, 20 \% \mathrm{~B}$; $11-15.5 \mathrm{~min}, 80 \% \mathrm{~B} ; 15.5-17.5 \mathrm{~min}, 80 \% \mathrm{~B} ; 17.5-19.5 \mathrm{~min}, 10 \% \mathrm{~B} ; 19.5-23 \mathrm{~min}, 10 \% \mathrm{~B}$. A $15 \mu \mathrm{L}$ aliquot of diluted extract was injected.

\subsubsection{Mycosporines and MAAs Profiling}

The screening of mycosporines and MAAs in Gelidium sesquipedale extracts were based on the untargeted (HILIC)—Electrospray Orbitrap $\mathrm{MS}^{2} / \mathrm{MS}^{3}$ analysis developed by 
Parailloux et al. [15]. A set of eight characteristic fragment ions, and neutral and radical losses produced in the fragmentation pathways of mycosporines and MAAs were defined to flag unreported candidate-compounds.

For this purpose, LC-MS experiments were carried out with the following the ESI conditions: sheath gas $50(\mathrm{arb})$, auxiliary gas 10 (arb), sweep gas 1 (arb), ion transfer tube and vaporizer temperature $350{ }^{\circ} \mathrm{C}$, rf lens $50 \%$ and positive ionization voltage $3500 \mathrm{~V}$. Full MS Orbitrap (OT) settings were: resolution 120,000, mass range $m / z$ 150-500, dynamic exclusion $5 \mathrm{~s}$ and intensity threshold $2 \times 10^{4}$. The ddMS2 OT settings were: resolution 60,000 for HCD70 MS /MS scans and 30,000 for HCD50 and CID30 MS/MS scans, isolation width $2 \mathrm{Da}$. The ddMS ${ }^{3}$ ion-trap (IT) settings were: scan rate $33,333 \mathrm{Da} / \mathrm{s}$, peak width 0.5 FWHM, isolation width $2 \mathrm{Da}$. HCD70 and CID30 MS² scans were used in parallel to generate both fragment ions, neutral losses and small radicals specific to the MAA compound class. Filtering criteria allowed the triggering of further ddMS ${ }^{2}$ HCD50 scans for structural elucidation of candidate-MAAs if characteristic fragment ions were detected in prior HCD70 $\mathrm{MS}^{2}$ scans. Likewise, neutral and small radical losses were included in the second filter triggering a ddMS ${ }^{3} \mathrm{CID} 30$ to confirm the detection of the candidate-MAAs found with the set of common fragment ions.

Data-treatment was performed on Compound Discoverer $3.2^{\mathrm{TM}}$ software (ThermoFisher Scientific, Waltham, MA, USA) for the MAA annotation in every extract. An untargeted workflow was designed to sort out the compounds detected for which the signal intensity was above $1 \times 10^{5}$ and the number of characteristic fragment ions was greater than or equal to four in their HCD70 MS² scan.

\subsubsection{Quantitative Analysis of MAAs}

The recovery of MAAs for the triplicate of different extraction methods was evaluated by quantifying porphyra-334, shinorine, palythine and asterina-330. The amounts of the three first compounds were determined in algal extracts using the standard addition method. The spiked extracts were analyzed in targeted Selected Ion Monitoring (SIM) with the following parameters: isolation width $1 \mathrm{~min}$; MS resolution 60,000. In absence of a standard, the quantification of asterina-330 was estimated assuming an electrospray MS response factor similar (within 10\%) to the standards. All the spikes were carried in algal extracts diluted 100 -fold.

\subsection{Spectrophotometric Determination of Phycobiliproteins}

Spectrophotometric determination of phycobiliproteins was performed following a previously described protocol for Gelidium pusillum [45]. R-PE and R-PC contents were estimated by measuring absorbance at $564 \mathrm{~nm}, 618 \mathrm{~nm}$ and $730 \mathrm{~nm}$ using a dual beam UV-visible spectrophotometer (Thermo Scientific ${ }^{\mathrm{TM}}$ Multiskan Sky, USA). The following equations were used for the estimation of phycobiliprotein contents:

$$
\begin{gathered}
\mathrm{R}-\mathrm{PE}=0.1247\left[\left(\mathrm{~A}_{564}-\mathrm{A}_{730}\right)-0.4583\left(\mathrm{~A}_{618}-\mathrm{A}_{730}\right)\right] \\
\left.\mathrm{R}-\mathrm{PC}=0.154\left(\mathrm{~A}_{618}-\mathrm{A}_{730}\right)\right] \\
\text { Total amount }=(\mathrm{R}-\mathrm{PE})+(\mathrm{R}-\mathrm{PC})
\end{gathered}
$$

All the experiments were carried out in triplicates.

\subsection{Antioxidant Capacity Analysis}

\subsubsection{DPPH Radical-Scavenging Assay}

The antioxidant activity was measured through the determination of the radical scavenging activity using 2,2- diphenyl-1-picrylhydrazyl (DPPH) [57]. Briefly, $250 \mu \mathrm{L}$ of $8.66 \times 10^{-5} \mathrm{M}$ DPPH methanolic solution was added to $50 \mu \mathrm{L}$ of sample/standard in a 96-well plate (Thermo Scientific ${ }^{\mathrm{TM}}$ Multiskan Sky, USA) and incubated in the dark at room temperature for $30 \mathrm{~min}$. The absorbance was measured at $\lambda 517 \mathrm{~nm}$. Distilled water was 
used as a blank. Each standard or sample solution was run in triplicate. The ability to scavenge the DPPH radical was calculated using the follow equation:

$$
\text { Scavenging effect }(\%)=\left[1-\left(\mathrm{A}_{\text {sample }}-\mathrm{A}_{\text {sample blank }}\right) / \mathrm{A}_{\text {control }}\right] \times 100
$$

where the $\mathrm{A}_{\text {control }}$ is the absorbance of the control (DPPH solution without sample), the $\mathrm{A}_{\text {sample }}$ is the absorbance of the test sample (DPPH solution plus test sample), and the $\mathrm{A}_{\text {sample blank }}$ is the absorbance of the sample only (sample without DPPH solution). Trolox standard was used to generate a standard curve and results were expressed as mg trolox equivalents (TE) per $100 \mathrm{~g}$ of dry algae (mg TE/100 g) [28].

\subsubsection{Ferric Reducing Antioxidant Power (FRAP) Assay}

The antioxidant activity of seaweeds extracts was measured using FRAP assay according to the Benzie and Strain [58] method, with some modifications [53]. First, the working FRAP solution was prepared mixing $300 \mathrm{mM}$ acetate buffer (pH 3.6), $10 \mathrm{mM}$ TPTZ $40 \mathrm{mM}$ $\mathrm{HCl}$ and $20 \mathrm{mM} \mathrm{FeCl}_{3}$ in a ratio 10:1:1 $(v / v / v)$. The FRAP solution was freshly prepared and warmed at $37^{\circ} \mathrm{C}$ for $10 \mathrm{~min}$. Then, $20 \mu \mathrm{L}$ of test sample solution was dispensed to each microplate well and the reaction was initiated by the addition of $200 \mu \mathrm{L}$ of the FRAP working solution. The reaction mixture was incubated at room temperature and in darkness for $10 \mathrm{~min}$. Finally, the absorbance was measured at $593 \mathrm{~nm}$. Trolox standard was used to make a standard curve and results were expressed as mg trolox equivalents (TE) per $100 \mathrm{~g}$ of dry algae (mg TE/100 g).

\subsection{Anti-Enzymatic Activities}

\subsubsection{Acetylcholinesterase (AChE) Inhibition Assay}

Acetylcholinesterase (AChE, Type-VI-S, EC 3.1.1.7, $222 \mathrm{U} / \mathrm{mg}$ ) inhibitory activity of extracts were determined according to previously described Ellman's colorimetric method [59]. Acetylthiocholine iodide was employed as the substrate to assay the inhibition of AChE. The reaction mixture contained $130 \mu \mathrm{L}$ of $100 \mathrm{mM}$ sodium phosphate buffer ( $\mathrm{pH}$ 8.0), $20 \mu \mathrm{L}$ of test sample solution and $20 \mu \mathrm{L}$ of $\mathrm{AChE}(0.36 \mathrm{U} / \mathrm{mL})$, which were mixed and incubated for $15 \mathrm{~min}$ at $25^{\circ} \mathrm{C}$. The reaction was then initiated via the addition of $40 \mu \mathrm{L}$ of the following mixture (freshly prepared): $20 \mu \mathrm{L} 0.5 \mathrm{mM}$ DTNB (5,5'-dithiobis (2-nitrobenzoic acid) and $20 \mu \mathrm{L}$ acetylthiocholine iodide $(0.71 \mathrm{mM})$. The hydrolysis of acetylthiocholine iodide was monitored by following the formation of yellow 5-thio-2-nitrobenzoate anion at $412 \mathrm{~nm}$ every $10 \mathrm{sec}$ for $10 \mathrm{~min}$ using a 96-well microplate reader under a constant temperature of $25^{\circ} \mathrm{C}$, which resulted from the reaction of 5-50-thiobis-2-nitrobenzoic acid with thiocholine, released by the enzymatic hydrolysis of acetylthiocholine iodide. The percent inhibition of acetylcholinesterase enzyme was calculated using the equation:

$$
\% \text { Inhibition }=\left[\left(\Delta \mathrm{Abs} / \mathrm{min}_{\text {control }}-\Delta \mathrm{Abs} / \mathrm{min}_{\text {sample }}\right) / \Delta \mathrm{Abs} / \mathrm{min}_{\text {control }}\right] \times 100
$$

where, $\mathrm{Abs}_{\text {control }}$ is the absorbance of the assay using the buffer instead of inhibitor (sample) and $\mathrm{Abs}_{\text {sample }}$ is the absorbance of the sample extracts. Neostigmine bromide was used as the positive control [49]. Phosphate buffer was used as the blank. Each standard or sample solution was analyzed in triplicate. The concentration of the extracts which caused $50 \%$ inhibition of the tyrosinase activity (IC50) was calculated by nonlinear regression analysis.

\subsubsection{Elastase Inhibition Assay}

The elastase inhibition of seaweeds extracts was investigated in TRIS buffer solution following the method of Eun et al. [60], with some modifications [61]. Briefly, $100 \mu \mathrm{L}$ of $0.1 \mathrm{M}$ Tris- $\mathrm{HCl}$ buffer solution ( $\mathrm{pH} 8.0), 25 \mu \mathrm{L}$ of elastase ( $1 \mathrm{U} / \mathrm{mL}$ in TRIS buffer) and $20 \mu \mathrm{L}$ sample extracts were incubated for $15 \mathrm{~min}$ at $25^{\circ} \mathrm{C}$, before adding the substrate to begin the reaction. After incubation time, $40 \mu \mathrm{L}$ of $0.5 \mathrm{mM} \mathrm{N}$-Succinyl-Ala-Ala-Ala-pnitroanilide (AAAPVN) solution in water was added. Following this, absorbance at $410 \mathrm{~nm}$ 
was monitored for $20 \mathrm{~min}$ using a microplate reader under a constant temperature of $25^{\circ} \mathrm{C}$. Finally, elastase inhibition was calculated in percentage using the equation:

$$
\% \text { Inhibition }=\left[\left(\Delta \mathrm{Abs} / \mathrm{min}_{\text {control }}-\Delta \mathrm{Abs} / \mathrm{min}_{\text {sample }}\right) / \Delta \mathrm{Abs} / \mathrm{min}_{\text {control }}\right] \times 100
$$

where, $\mathrm{Abs}_{\text {contro }} \mathrm{l}$ is the absorbance of the assay using the buffer instead of inhibitor (sample) and $\mathrm{Abs}_{\text {sample }}$ is the absorbance of the sample extracts. Quercetin was used as the positive control [61]. Tris- $\mathrm{HCl}$ buffer was used as the blank. Each standard or sample solution was analyzed in triplicate. The concentration of the extracts which caused $50 \%$ inhibition of the tyrosinase activity (IC50) was calculated by nonlinear regression analysis.

\subsubsection{Tyrosinase Inhibition Assay}

Tyrosinase inhibitory assay was performed according to the method previously described by [61], with some modifications using 3,4-Dihydroxy-L-phenylalanine (L-DOPA) as substrate. A volume of $20 \mu \mathrm{L}$ of sample, $20 \mu \mathrm{L}$ of mushroom tyrosinase solution $(100 \mathrm{U} / \mathrm{mL}$ in phosphate buffer) and $80 \mu \mathrm{L}$ of phosphate buffer $(\mathrm{pH}=6.8)$ were mixed and pre-incubated at $37^{\circ} \mathrm{C}$ for $5 \mathrm{~min}$. Then, $90 \mu \mathrm{L}$ of L-DOPA $(2 \mathrm{mg} / \mathrm{mL}$ water $)$ was added. The formation of dopachrome was immediately monitored for $20 \mathrm{~min}$ at $475 \mathrm{~nm}$ in a microplate reader under constant temperature of $37^{\circ} \mathrm{C}$. The percent inhibition of tyrosinase enzyme was calculated using the equation:

$$
\% \text { Inhibition }=\left[\left(\Delta \mathrm{Abs} / \mathrm{min}_{\text {control }}-\Delta \mathrm{Abs} / \mathrm{min}_{\text {sample }}\right) / \Delta \mathrm{Abs} / \mathrm{min}_{\text {control }}\right] \times 100
$$

where, $\mathrm{Abs}_{\text {control }}$ is the absorbance of the assay using the buffer instead of the inhibitor

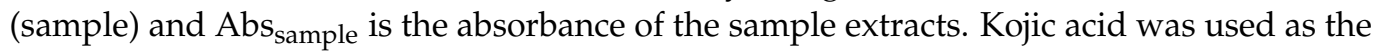
positive control. Phosphate buffer was used as the blank. Each standard or sample solution was analyzed in triplicate. The concentration of the extracts which caused 50\% inhibition of the tyrosinase activity (IC50) was calculated by nonlinear regression analysis.

\subsection{Statistical Analysis}

All the experiments were carried out in triplicate. Results are expressed as mean \pm standard deviation. Statistical analysis was performed using JASP version 0.14.1 (University of Amsterdam, Netherlands). The effect of extraction method, extraction time and solvents on the bioactives recovery and associated antioxidant and anti-enzymatic activities were analyzed using ANOVA followed by Tukey's HSD post-hoc tests. In all cases, differences were considered statistically significant at $p<0.05$.

\section{Conclusions}

The present study provides relevant results for the development of eco-friendly approaches to reach a superior valorization of the red algae Gelidium sesquispedale by extracting high-valuable bioactives such as phenolic and flavonoid compounds, mycosporine-like amino acids, and phycobiliproteins. The green methods developed using ultrasoundassisted extraction and the combination of green solvents showed a promising alternative to efficiently extract a broad spectrum of minor compounds, achieving comparable extraction yields to traditional methods in very short times ( 15 to $30 \mathrm{~min}$ vs. $8 \mathrm{~h}$ for the conventional method). Additionally, produced algal extracts exhibited interesting antioxidant and anti-enzymatic activities for potential applications in medical and/or cosmetic products. Thus, this study shows the importance of eco-friendly methods to studying novel properties of algal biomass to provide new valorization routes. The proposed extraction methods not only open new possibilities for the commercial use of Gelidium sesquipedale, but also for the valorization of different algae species since the techniques established can be easily adapted, proving the usefulness of green strategies to extract bioactive compounds from algal biomass. 
Supplementary Materials: The following are available online at https: / www.mdpi.com/article/ $10.3390 / \mathrm{md19100574/s1;} \mathrm{Figure} \mathrm{S1:} \mathrm{UV} \mathrm{absorption} \mathrm{spectra}(\lambda=300-750 \mathrm{~nm})$ of Gelidium sesquipedale extracts using ultrasound-assisted extraction and conventional solvent extraction techniques; Figure S2: MS² Spectra of candidate-MAAs identified in the algal species Gelidium sesquipedale.

Author Contributions: Conceptualization, N.C. and S.C.M.F.; methodology, N.C. carried out the main part of the experimental work, M.P. and A.I. carried out the MAAs analyses; investigation, N.C. and S.C.M.F. conducted the main part of the manuscript, M.P., A.I. and R.L. were implied in the MAAs determination; data curation-formal analysis, N.C. carried out the main part of the data evaluation, M.P. and A.I. analyzed the data for the MAAs analyses; writing-original draft preparation, N.C. wrote the main part of manuscript, M.P. wrote the MAAs section; writing-review and editing, N.C. and S.C.M.F. wrote, reviewed and edited the entire manuscript, M.P. and R.L. wrote, reviewed and edited the MAAs section; funding acquisition, S.C.M.F. All authors have read and agreed to the published version of the manuscript.

Funding: This work was carried under the framework of E2S UPPA Partnership Chair MANTA (Marine Materials) funded by the 'Investissements d'Avenir' French program managed by ANR, grant number \#ANR-16-IDEX-0002; by the Région Nouvelle-Aquitaine and by the Communauté d'Agglomération du Pays Basque (France); and by the FLAG "Côte basque-Sud Landes" through the community-led local development (CLDD: ref number \# PFEA621219CR0720024) program funded by the European Maritime and Fisheries Fund (EMFF) and the Région Nouvelle-Aquitaine, France. S.C.M.F. would like to thank FORMAS, the Swedish Research Council for Sustainable Development, for the grant number \# 2016-00795.

Acknowledgments: The authors thank the local fishery committee, the CIDPMEM 64-40, in particular Nicolas Susperregui for kindly providing the local red algae samples, and Colin McReynolds for the transportation of the biomass. The authors also thank Maxime Ekoule for helping with the experimental work of the phycobiliproteins extraction.

Conflicts of Interest: The authors declare no conflict of interest.

\section{References}

1. Rengasamy, K.R.; Mahomoodally, M.F.; Aumeeruddy, M.Z.; Zengin, G.; Xiao, J.; Kim, D.H. Bioactive Compounds in Seaweeds: An Overview of Their Biological Properties and Safety. Food Chem. Toxicol. 2020, 135, 111013. [CrossRef]

2. Ma, R.; Wang, B.; Chua, E.T.; Zhao, X.; Lu, K.; Ho, S.-H.; Shi, X.; Liu, L.; Xie, Y.; Lu, Y.; et al. Comprehensive Utilization of Marine Microalgae for Enhanced Co-Production of Multiple Compounds. Mar. Drugs 2020, 18, 467. [CrossRef]

3. Torres, M.D.; Flórez-Fernández, N.; Domínguez, H. Integral Utilization of Red Seaweed for Bioactive Production. Mar. Drugs 2019, 17, 314. [CrossRef] [PubMed]

4. Ferrera-Lorenzo, N.; Fuente, E.; Suárez-Ruiz, I.; Gil, R.R.; Ruiz, B. Pyrolysis Characteristics of a Macroalgae Solid Waste Generated by the Industrial Production of Agar-Agar. J. Anal. Appl. Pyrolysis 2014, 105, 209-216. [CrossRef]

5. Herrero, M.; Sánchez-Camargo, A.d.P.; Cifuentes, A.; Ibáñez, E. Plants, Seaweeds, Microalgae and Food by-Products as Natural Sources of Functional Ingredients Obtained Using Pressurized Liquid Extraction and Supercritical Fluid Extraction. TrAC Trends Anal. Chem. 2015, 71, 26-38. [CrossRef]

6. Gallego, R.; Bueno, M.; Herrero, M. Sub- and Supercritical Fluid Extraction of Bioactive Compounds from Plants, Food-byProducts, Seaweeds and Microalgae-An Update. TrAC Trends Anal. Chem. 2019, 116, 198-213. [CrossRef]

7. European Commission Report on the Blue Growth Strategy: Towards More Sustainable Growth and Jobs in the Blue Economy; European Union: Brussels, Belgium, 2017.

8. Carrasco-Reinado, R.; Escobar, A.; Carrera, C.; Guarnizo, P.; Vallejo, R.A.; Fernández-Acero, F.J. Valorization of Microalgae Biomass as a Potential Source of High-Value Sugars and Polyalcohols. LWT 2019, 114, 108385. [CrossRef]

9. Pérez, M.J.; Falqué, E.; Domínguez, H. Antimicrobial Action of Compounds from Marine Seaweed. Mar. Drugs 2016, 14, 52. [CrossRef]

10. Grina, F.; Ullah, Z.; Kaplaner, E.; Moujahid, A.; Eddoha, R.; Nasser, B.; Terzioğlu, P.; Yilmaz, M.A.; Ertaş, A.; Öztürk, M.; et al. In Vitro Enzyme Inhibitory Properties, Antioxidant Activities, and Phytochemical Fingerprints of Five Moroccan Seaweeds. South Afr. J. Bot. 2020, 128, 152-160. [CrossRef]

11. Grozdanic, N.; Stanojkovic, T.P.; Kljajic, Z.; Etahiri, S.; Assobhei, O.; Konic-Ristic, A.; Srdic-Rajic, T.; Kardum, N.; Backovic, S. 105 In Vitro Evaluation of Antioxidant and Antitumoral Activities of Marine Algae Gelidium Sesquipedale and Fucus Spiralis. Eur. J. Cancer 2012, 48, S26. [CrossRef]

12. Lebbar, S.; Fanuel, M.; Le Gall, S.; Falourd, X.; Ropartz, D.; Bressollier, P.; Gloaguen, V.; Faugeron-Girard, C. Agar Extraction By-Products from Gelidium Sesquipedale as a Source of Glycerol-Galactosides. Molecules 2018, 23, 3364. [CrossRef] 
13. Matos, J.; Gomes, A.; Cardoso, C.; Afonso, C.; Campos, A.M.; Gomes, R.; Falé, P.; Delgado, I.; Coelho, I.; Castanheira, I.; et al. Commercial Red Seaweed in Portugal (Gelidium Sesquipedale and Pterocladiella Capillacea, Florideophyceae): Going beyond a Single-Purpose Product Approach by Valorizing Bioactivity. Thalassas 2020, 36, 213-224. [CrossRef]

14. Álvarez-Viñas, M.; Flórez-Fernández, N.; Torres, M.D.; Domínguez, H. Successful Approaches for a Red Seaweed Biorefinery. Mar. Drugs 2019, 17, 620. [CrossRef] [PubMed]

15. Parailloux, M.; Godin, S.; Fernandes, S.C.M.; Lobinski, R. Untargeted Analysis for Mycosporines and Mycosporine-Like Amino Acids by Hydrophilic Interaction Liquid Chromatography (HILIC)—Electrospray Orbitrap MS2/MS3. Antioxidants 2020, 9. [CrossRef]

16. Trigueros, E.; Sanz, M.T.; Alonso-Riaño, P.; Beltrán, S.; Ramos, C.; Melgosa, R. Recovery of the Protein Fraction with High Antioxidant Activity from Red Seaweed Industrial Solid Residue after Agar Extraction by Subcritical Water Treatment. J. Appl. Phycol. 2021, 33, 1181-1194. [CrossRef]

17. Castejón, N.; Luna, P.; Señoráns, F.J. Alternative Oil Extraction Methods from Echium Plantagineum L. Seeds Using Advanced Techniques and Green Solvents. Food Chem. 2018, 244, 75-82. [CrossRef]

18. Tiwari, B.K. Ultrasound: A Clean, Green Extraction Technology. TrAC Trends Anal. Chem. 2015, 71, 100-109. [CrossRef]

19. Synytsya, A.; Čopíková, J.; Kim, W.J.; Park, Y.I. Cell Wall Polysaccharides of Marine Algae. In Springer Handbook of Marine Biotechnology; Kim, S.-K., Ed.; Springer: Berlin/Heidelberg, Germany, 2015; pp. 543-590. ISBN 978-3-642-53971-8.

20. Demuez, M.; Mahdy, A.; Tomás-Pejó, E.; González-Fernández, C.; Ballesteros, M. Enzymatic Cell Disruption of Microalgae Biomass in Biorefinery Processes. Biotechnol. Bioeng. 2015, 112, 1955-1966. [CrossRef]

21. Garcia-Vaquero, M.; Ummat, V.; Tiwari, B.; Rajauria, G. Exploring Ultrasound, Microwave and Ultrasound-Microwave Assisted Extraction Technologies to Increase the Extraction of Bioactive Compounds and Antioxidants from Brown Macroalgae. Mar. Drugs 2020, 18. [CrossRef] [PubMed]

22. Chemat, F.; Rombaut, N.; Sicaire, A.-G.; Meullemiestre, A.; Fabiano-Tixier, A.-S.; Abert-Vian, M. Ultrasound Assisted Extraction of Food and Natural Products. Mechanisms, Techniques, Combinations, Protocols and Applications. A Review. Ultrason. Sonochem. 2017, 34, 540-560. [CrossRef] [PubMed]

23. Cotas, J.; Leandro, A.; Monteiro, P.; Pacheco, D.; Figueirinha, A.; Gonçalves, A.M.M.; da Silva, G.J.; Pereira, L. Seaweed Phenolics: From Extraction to Applications. Mar. Drugs 2020, 18. [CrossRef] [PubMed]

24. Zhu, H.; Wang, Y.; Liu, Y.; Xia, Y.; Tang, T. Analysis of Flavonoids in Portulaca Oleracea L. by UV-Vis Spectrophotometry with Comparative Study on Different Extraction Technologies. Food Anal. Methods 2010, 3, 90-97. [CrossRef]

25. Singh, J.; Jayaprakasha, G.K.; Patil, B.S. An Optimized Solvent Extraction and Characterization of Unidentified Flavonoid Glucuronide Derivatives from Spinach by UHPLC-HR-QTOF-MS. Talanta 2018, 188, 763-771. [CrossRef]

26. Mane, S.; Bremner, D.H.; Tziboula-Clarke, A.; Lemos, M.A. Effect of Ultrasound on the Extraction of Total Anthocyanins from Purple Majesty Potato. Ultrason. Sonochem. 2015, 27, 509-514. [CrossRef] [PubMed]

27. Getachew, A.T.; Jacobsen, C.; Holdt, S.L. Emerging Technologies for the Extraction of Marine Phenolics: Opportunities and Challenges. Mar. Drugs 2020, 18. [CrossRef] [PubMed]

28. Ummat, V.; Tiwari, B.K.; Jaiswal, A.K.; Condon, K.; Garcia-Vaquero, M.; O’Doherty, J.; O’Donnell, C.; Rajauria, G. Optimisation of Ultrasound Frequency, Extraction Time and Solvent for the Recovery of Polyphenols, Phlorotannins and Associated Antioxidant Activity from Brown Seaweeds. Mar. Drugs 2020, 18, 250. [CrossRef] [PubMed]

29. Metidji, H.; Dob, T.; Mohamed, T.; Krimat, S.; Ksouri, A.; Nouasri, A. In Vitro Screening of Secondary Metabolites and Evaluation of Antioxidant, Antimicrobial and Cytotoxic Properties of Gelidium Sesquipedale Thuret et Bornet Red Seaweed from Algeria. J. Mater. Environ. Sci. 2015, 6, 3184-3196.

30. Xu, P.; Tan, H.; Jin, W.; Li, Y.; Santhoshkumar, C.; Li, P.; Liu, W. Antioxidative and Antimicrobial Activities of Intertidal Seaweeds and Possible Effects of Abiotic Factors on These Bioactivities. J. Ocean. Limnol. 2018, 36, 2243-2256. [CrossRef]

31. de la Coba, F.; Aguilera, J.; Lopez Figueroa, F.; de Gálvez, M.; Herrera-Ceballos, E. Antioxidant Activity of Mycosporine-like Amino Acids Isolated from Three Red Macroalgae and One Marine Lichen. J. Appl. Phycol. 2008, 21, 161-169. [CrossRef]

32. Nishida, Y.; Kumagai, Y.; Michiba, S.; Yasui, H.; Kishimura, H. Efficient Extraction and Antioxidant Capacity of Mycosporine-Like Amino Acids from Red Alga Dulse Palmaria Palmata in Japan. Mar. Drugs 2020, 18, 502. [CrossRef]

33. Cardozo, K.; Marques, L.; Carvalho, V.; Carignan, M.; Pinto, E.; Marinho-Soriano, E.; Colepicolo, P. Analyses of Photoprotective Compounds in Red Algae from the Brazilian Coast. Rev. Bras. De Farmacogn. Braz. J. Pharmacogn. 2011, 21, 202-208. [CrossRef]

34. Claverie, M.; McReynolds, C.; Petitpas, A.; Thomas, M.; Fernandes, S.C.M. Marine-Derived Polymeric Materials and Biomimetics: An Overview. Polymers 2020, 12, 1002. [CrossRef]

35. Fernandes, S.C.M.; Alonso-Varona, A.; Palomares, T.; Zubillaga, V.; Labidi, J.; Bulone, V. Exploiting Mycosporines as Natural Molecular Sunscreens for the Fabrication of UV-Absorbing Green Materials. ACS Appl. Mater. Interfaces 2015, 7, 16558-16564. [CrossRef] [PubMed]

36. de la Coba, F.; Aguilera, J.; Korbee, N.; de Gálvez, M.V.; Herrera-Ceballos, E.; Álvarez-Gómez, F.; Figueroa, F.L. UVA and UVB Photoprotective Capabilities of Topical Formulations Containing Mycosporine-like Amino Acids (MAAs) through Different Biological Effective Protection Factors (BEPFs). Mar. Drugs 2019, 17, 55. [CrossRef]

37. Wada, N.; Sakamoto, T.; Matsugo, S. Mycosporine-Like Amino Acids and Their Derivatives as Natural Antioxidants. Antioxidants 2015, 4, 603-646. [CrossRef] 
38. Lee, T.-M.; Shiu, C.-T. Implications of Mycosporine-like Amino Acid and Antioxidant Defenses in UV-B Radiation Tolerance for the Algae Species Ptercladiella Capillacea and Gelidium Amansii. Mar. Environ. Res. 2009, 67, 8-16. [CrossRef]

39. Chan, P.T.; Matanjun, P.; Yasir, S.M.; Tan, T.S. Antioxidant Activities and Polyphenolics of Various Solvent Extracts of Red Seaweed, Gracilaria Changii. J. Appl. Phycol. 2015, 27, 2377-2386. [CrossRef]

40. Zakaria, N.A.; Ibrahim, D.; Sulaiman, S.F.; Supardy, A. Assessment of Antioxidant Activity, Total Phenolic Content and in-Vitro Toxicity of Malaysian Red Seaweed, Acanthophora Spicifera. J. Chem. Pharm. Res. 2011, 3, 182-191.

41. Farasat, M.; Khavari-Nejad, R.-A.; Nabavi, S.M.B.; Namjooyan, F. Antioxidant Activity, Total Phenolics and Flavonoid Contents of Some Edible Green Seaweeds from Northern Coasts of the Persian Gulf. Iran. J. Pharm. Res. IJPR 2014, $13,163$.

42. Li, W.; Su, H.-N.; Pu, Y.; Chen, J.; Liu, L.-N.; Liu, Q.; Qin, S. Phycobiliproteins: Molecular Structure, Production, Applications, and Prospects. Biotechnol. Adv. 2019, 37,340-353. [CrossRef]

43. Kannaujiya, V.K.; Kumar, D.; Pathak, J.; Sinha, R.P. Chapter 10-Phycobiliproteins and Their Commercial Significance. In Cyanobacteria; Mishra, A.K., Tiwari, D.N., Rai, A.N., Eds.; Academic Press: Cambridge, MA, USA, 2019; pp. 207-216. ISBN 978-0-12-814667-5.

44. Pagels, F.; Guedes, A.C.; Amaro, H.M.; Kijjoa, A.; Vasconcelos, V. Phycobiliproteins from Cyanobacteria: Chemistry and Biotechnological Applications. Biotechnol. Adv. 2019, 37, 422-443. [CrossRef]

45. Mittal, R.; Tavanandi, H.A.; Mantri, V.A.; Raghavarao, K.S.M.S. Ultrasound Assisted Methods for Enhanced Extraction of Phycobiliproteins from Marine Macro-Algae, Gelidium Pusillum (Rhodophyta). Ultrason. Sonochem. 2017, 38, 92-103. [CrossRef]

46. Sharma, R.; Bhunia, B.; Mondal, A.; Kanti Bandyopadhyay, T.; Devi, I.; Oinam, G.; Prasanna, R.; Abraham, G.; Nath Tiwari, O. Statistical Optimization of Process Parameters for Improvement of Phycobiliproteins (PBPs) Yield Using Ultrasound-Assisted Extraction and Its Kinetic Study. Ultrason. Sonochem. 2020, 60, 104762. [CrossRef]

47. Sukwong, P.; Sunwoo, I.Y.; Nguyen, T.H.; Jeong, G.-T.; Kim, S.-K. R-Phycoerythrin, R-Phycocyanin and ABE Production from Gelidium Amansii by Clostridium Acetobutylicum. Process Biochem. 2019, 81, 139-147. [CrossRef]

48. Agatonovic-Kustrin, S.; Kettle, C.; Morton, D.W. A Molecular Approach in Drug Development for Alzheimer's Disease. Biomed. Pharmacother. 2018, 106, 553-565. [CrossRef]

49. Moodie, K.L.W.; Sepčić, K.; Turk, T.; Frangež, R.; Svenson, J. Natural Cholinesterase Inhibitors from Marine Organisms. Nat. Prod. Rep. 2019, 36, 1053-1092. [CrossRef]

50. Pillaiyar, T.; Manickam, M.; Namasivayam, V. Skin Whitening Agents: Medicinal Chemistry Perspective of Tyrosinase Inhibitors. J. Enzym. Inhib. Med. Chem. 2017, 32, 403-425. [CrossRef] [PubMed]

51. Chiocchio, I.; Mandrone, M.; Sanna, C.; Maxia, A.; Tacchini, M.; Poli, F. Screening of a Hundred Plant Extracts as Tyrosinase and Elastase Inhibitors, Two Enzymatic Targets of Cosmetic Interest. Ind. Crop. Prod. 2018, 122, 498-505. [CrossRef]

52. Oumaskour, K.; Boujaber, N.; Etahiri, S.; Assobhei, O. Anti-Inflammatory and Antimicrobial Activities of Twenty-Tree Marine Red Algae from the Coast of Sidi Bouzid (El Jadida-Morocco). Int. J. Pharm. Pharm. Sci. 2013, 5, 145-149.

53. Matanjun, P.; Mohamed, S.; Mustapha, N.M.; Muhammad, K.; Ming, C.H. Antioxidant Activities and Phenolics Content of Eight Species of Seaweeds from North Borneo. J. Appl. Phycol. 2008, 20, 367. [CrossRef]

54. Zhang, Q.; Zhang, J.; Shen, J.; Silva, A.; Dennis, D.A.; Barrow, C.J. A Simple 96-Well Microplate Method for Estimation of Total Polyphenol Content in Seaweeds. J. Appl. Phycol. 2006, 18, 445-450. [CrossRef]

55. Duan, X.-J.; Zhang, W.-W.; Li, X.-M.; Wang, B.-G. Evaluation of Antioxidant Property of Extract and Fractions Obtained from a Red Alga, Polysiphonia Urceolata. Food Chem. 2006, 95, 37-43. [CrossRef]

56. Chang, C.-C.; Yang, M.-H.; Wen, H.-M.; Chern, J.-C. Estimation of Total Flavonoid Content in Propolis by Two Complementary Colorimetric Methods. J. Food Drug Anal. 2002, 10, 178-182.

57. Neto, R.T.; Marçal, C.; Queirós, A.S.; Abreu, H.; Silva, A.M.S.; Cardoso, S.M. Screening of Ulva Rigida, Gracilaria Sp., Fucus Vesiculosus and Saccharina Latissima as Functional Ingredients. Int. J. Mol. Sci. 2018, 19, 2987. [CrossRef] [PubMed]

58. Benzie, I.F.F.; Strain, J.J. The Ferric Reducing Ability of Plasma (FRAP) as a Measure of “Antioxidant Power": The FRAP Assay. Anal. Biochem. 1996, 239, 70-76. [CrossRef] [PubMed]

59. Ellman, G.L.; Courtney, K.D.; Andres, V.; Featherstone, R.M. A New and Rapid Colorimetric Determination of Acetylcholinesterase Activity. Biochem. Pharmacol. 1961, 7, 88-95. [CrossRef]

60. Eun Lee, K.; Bharadwaj, S.; Yadava, U.; Gu Kang, S. Evaluation of Caffeine as Inhibitor against Collagenase, Elastase and Tyrosinase Using in Silico and in Vitro Approach. J. Enzym. Inhib. Med. Chem. 2019, 34, 927-936. [CrossRef]

61. Liyanaarachchi, G.D.; Samarasekera, J.K.R.R.; Mahanama, K.R.R.; Hemalal, K.D.P. Tyrosinase, Elastase, Hyaluronidase, Inhibitory and Antioxidant Activity of Sri Lankan Medicinal Plants for Novel Cosmeceuticals. Ind. Crop. Prod. 2018, 111, 597-605. [CrossRef] 